\title{
Synthesis and Antiretroviral Evaluation of Derivatives of Zidovudine
}
Mónica A. Raviolo, ${ }^{a}$ Juan S. Trinchero-Hernández, ${ }^{b}$ Gabriela Turk ${ }^{b}$ and Margarita C. Briñón*,a \\ ${ }^{a}$ Departamento de Farmacia, Facultad de Ciencias Químicas, Ciudad Universitaria, \\ Universidad Nacional de Córdoba, 5000 Córdoba, Argentina \\ ${ }^{b}$ Centro Nacional de Referencia para el SIDA, Departamento de Microbiología, \\ Facultad de Medicina, Universidad de Buenos Aires, Buenos Aires, Argentina
}

\begin{abstract}
Uma série de novos carbamatos de zidovudina (AZT, 1) foi sintetizada, caracterizada e avaliada em relação a sua atividade anti-HIV e citotoxicidade. O grupo hidroxila da posição 5' do AZT foi derivatizado usando-se $N, N$ '-carbonildiimidazol e diferentes aminas para gerar os respectivos 5'-O-carbamatos. Além disso, dois derivados já conhecidos foram sintetizados, um 5'-O-tosilato e um derivado tricíclico (AZT-Cycl), empregando-se métodos mais rápidos e simples do que os previamente reportados. Embora os novos derivados tenham apresentado menor toxicidade do que o AZT, essa redução na citotoxicidade foi concomitante com a marcada diminuição para inibir a replicação do vírus, com exceção do AZT-Cycl, o qual, mesmo apresentando $\mathrm{IC}_{50}=1 \mu \mathrm{mol} \mathrm{L} \mathrm{L}^{-1}$, não demonstrou sinais de citotoxicidade com valores de $\operatorname{CCID}_{50}\left(\mu \mathrm{mol} \mathrm{L} \mathrm{L}^{-1}\right)>1000$.
\end{abstract}

A series of zidovudine (AZT, 1) derivatives have been synthesized and their anti-HIV activity and cytotoxicity have been determined. The 5'-OH function of AZT was derivatized using $N$, $N^{\prime}$-carbonyldiimidazole and different amine compounds leading to their 5'-O-carbamates. In addition, two known AZT derivatives 5'-O-tosylate and a tricyclic one (AZT-Cycl) were also obtained by a simpler procedure than those previously reported. Although these AZT derivatives were less toxic than AZT, their reduced cytotoxicity was concomitant with an inability to inhibit HIV-1 replication, except in the case of AZT-Cycl, which showed an $\mathrm{IC}_{50}=1 \mu \mathrm{mol} \mathrm{\textrm {L } ^ { - 1 }}$ without cytotoxicity with values of $\mathrm{CCID}_{50}\left(\mu \mathrm{mol} \mathrm{L}{ }^{-1}\right)>1000$.

Keywords: zidovudine analogs, anti-HIV activity, cytotoxicity

\section{Introduction}

The rapid worldwide spread of acquired immunodeficiency syndrome (AIDS) has prompted an intense research effort to try to discover compounds that can effectively inhibit the human immunodeficiency virus (HIV),${ }^{1}$ the etiological agent of AIDS. ${ }^{2}$ However, despite the worldwide attempts underway to develop chemotherapeutic agents effective against HIV, 3'-azido2',3'-dideoxythymidine (zidovudine, AZT, 1), the first drug approved for the treatment of patients suffering from AIDS, ${ }^{3}$ is still one of the most potent active agents against $\mathrm{HIV}$, and is used as a primary option in AIDS treatment in combination with other HIV inhibitors. Once AZT is converted into its 5 '- $O$-triphosphate analog by cellular kinases, it inhibits HIV reverse transcriptase, a key factor in

\footnotetext{
*e-mail: macribri@fcq.unc.edu.ar
}

the initiation of HIV replication, and thus terminates DNA chain synthesis from viral RNA inside the infected cells. ${ }^{4}$

The utility of AZT is limited by its toxic effect on bone marrow, ${ }^{5}$ hepatic abnormalities, ${ }^{6}$ limited brain uptake, ${ }^{7}$ short half-life in plasma, ${ }^{8}$ high susceptibility to catabolism ${ }^{9}$ and rapid progress of resistance by HIV-1. ${ }^{10,11}$ For these reasons, numerous chemical strategies have been developed by medicinal scientists to design prodrugs of AZT, in order to increase its therapeutic efficacy. ${ }^{12,13}$ Most of these have been prepared derivatizing the 5'-OH of AZT, whose mechanism of action is based on hydrolysis and/or enzymatic cleavage of their 5'-O-bonds between the drug (AZT) and its attached moiety.

We here report the synthesis, characterization, antiHIV activity, cytotoxicity in cell cultures and enzymatic stability of novel AZT derivatives (4-7), and of two known compounds, a tosyl (2) and a tricyclic analog (3), prepared by a simpler procedure than that previously reported. ${ }^{14}$ 

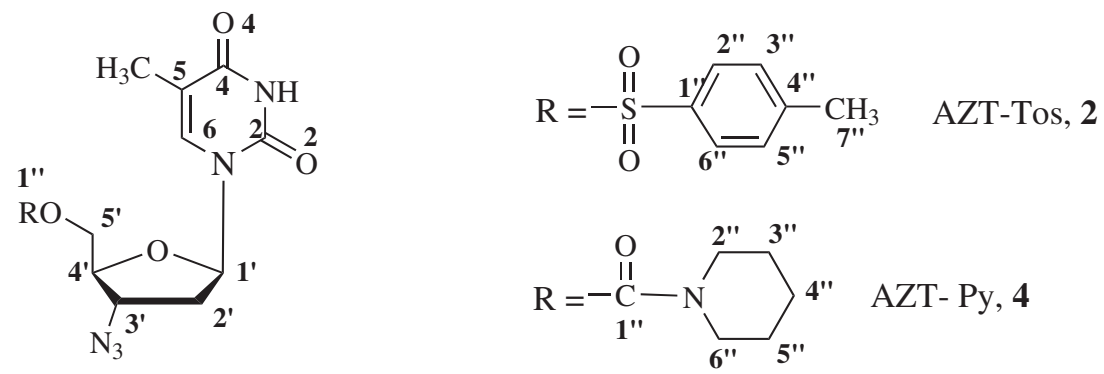

$\mathrm{R}=\mathrm{H} ; \mathrm{AZT}, \mathbf{1}$

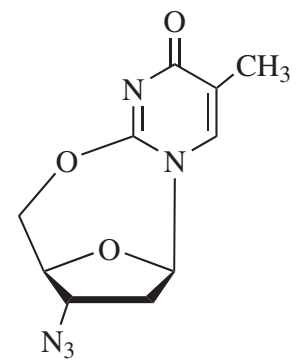

AZT-Cycl, 3

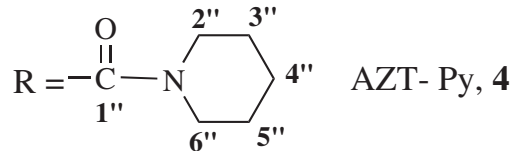

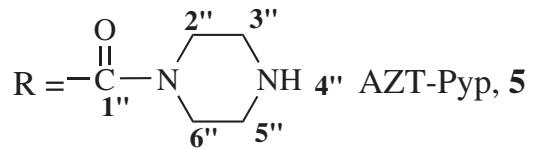<smiles></smiles><smiles>[R]C(=O)Nc1ccn[nH]1</smiles>

Figure 1. Chemical structure of Zidovudine and its derivatives.

It is important to point out that ${ }^{13} \mathrm{C}$-NMR spectra of $\mathbf{2}$ and 3 were not previously reported (Figure 1).

\section{Results and Discussion}

\section{Chemistry}

Both AZT-O-5' -tosyl (AZT-Tos, 2) and tricyclic derivative (AZT-Cycl, 3) have been previously obtained by Lin et $a l ;{ }^{14}$ however, in the present work these compounds were synthesized by simple methods. Thus, $\mathbf{2}$ was obtained in $80 \%$ yield from AZT and tosyl chloride in pyridine at $0{ }^{\circ} \mathrm{C}$ for $8 \mathrm{~h}$ (Table 1 ).

When 2 was assayed with various amines under different reaction conditions, the expected 5'-amine derivatives of
AZT were not obtained, ${ }^{15,16}$ leading to tricyclic analog (3) (Figure 1). Although total conversion of $\mathbf{2}$ took place, only $50 \%$ yield of $\mathbf{3}$ was obtained as side reaction products were formed, which were not identified, except AZT, the main co-product. It should be noted that $\mathbf{3}$ was obtained in a simpler procedure employing only one step, yet producing an overall similar yield.

Thus, compound $\mathbf{3}$ was formed through an initial deprotonation of the pyrimidinic $\mathrm{NH}$ group, resulting in a resonance ion structure intermediate with its negative charge distributed among $\mathrm{O}_{2}-\mathrm{C}_{2}-\mathrm{N}_{3}-\mathrm{C}_{4}-\mathrm{O}_{4}$ atoms (see Figure 1). This intermediate was susceptible to regiospecific intramolecular nucleophilic attack on the C-5' of the sugar moiety, with the tosyl group as the leaving one and the consequent formation of an additional ring. It is known that pyrimidinic nucleoside

Table 1. Reaction conditions of the synthesized compounds 2-7 and the intermediates of the reaction

\begin{tabular}{lll}
\hline Compound & Reaction conditions & Reagents \\
\hline AZT-Tos (2) & $\mathrm{Py}, 0{ }^{\circ} \mathrm{C}, 8 \mathrm{~h}$ & $\mathbf{1}+$ Tosyl Chloride \\
AZT-Cycl (3) & $\mathrm{DMF}($ reflux $), \mathrm{Na}_{2} \mathrm{CO}_{3}(\mathrm{exc}), 24 \mathrm{~h}$ & $\mathbf{2}$ \\
AZT-CI $^{\mathrm{b}}$ & $\mathrm{CH}_{3} \mathrm{CN}, \mathrm{N}_{2}, 40^{\circ} \mathrm{C}, 5 \mathrm{~h}$ & $\mathbf{1}+\mathrm{CDI}^{\mathrm{c}}$ \\
AZT-Py (4) & $\mathrm{CH}_{3} \mathrm{CN}, \mathrm{N}_{2}, 40^{\circ} \mathrm{C}$ & AZT-CI + Piperidine \\
AZT-Pyp (5) & $\mathrm{CH}_{3} \mathrm{CN}, \mathrm{N}_{2}, 40^{\circ} \mathrm{C}$ & AZT-CI + Piperazine \\
AZT-Ethy (6) & $\mathrm{CH}_{3} \mathrm{CN}, \mathrm{N}_{2}, 40^{\circ} \mathrm{C}$ & AZT-CI + 2-(1-piperazinyl)ethylamine \\
AZT-Aphy (7) & $\mathrm{CH}_{3} \mathrm{CN}, \mathrm{N}_{2}, 40^{\circ} \mathrm{C}$ & AZT-CI + 3-aminopyrazole \\
\hline
\end{tabular}

${ }^{\text {a } Y i e l d ~ o f ~ i s o l a t e d ~ p r o d u c t, ~}{ }^{\mathrm{b}} \mathrm{CI}$ : carbonylimidazole, ${ }^{\mathrm{c}} \mathrm{CDI}: N, N$ '-carbonyldiimidazole, ${ }^{\mathrm{d}} \mathrm{ND}$ : Not determined. 
derivatives present two conformations as a consequence of the glycosyl torsion angle. ${ }^{17,18}$ This angle determines the syn or anti disposition of the base in relation to the sugar moiety, where only one is favored with respect to the other, leading to the desired product.

Novel 5'-O-carbamate-AZT derivatives (4-7) were obtained by condensation of AZT with $N, N^{\prime}$ carbonyldiimidazole in $\mathrm{CH}_{3} \mathrm{CN}$ in the presence of amines such as piperidine, piperazine, 2-(1-piperazinyl)ethylamine and 3-aminopyrazole, following an improved procedure previously reported by other authors (Scheme 1). ${ }^{19-21}$ The yields obtained ranged from $71 \%$ to $82 \%$ for $\mathbf{4 - 6}$, and $11 \%$ for 7 (Table 1).

The structure of nucleoside derivatives 2-7 were determined by ${ }^{1} \mathrm{H}-\mathrm{NMR},{ }^{13} \mathrm{C}-\mathrm{NMR}, 135^{\circ} \mathrm{DEPT}$ (Distortionless Enhancement by Polarization Transfer), COSY (Correlation Spectroscopy, ${ }^{1} \mathrm{H}-{ }^{1} \mathrm{H}$ ) and HETCOR (Heteronuclear Correlations, ${ }^{13} \mathrm{C}-{ }^{1} \mathrm{H}$ ) nuclear magnetic and IR spectroscopic techniques. The ${ }^{1} \mathrm{H}-\mathrm{NMR}$ and ${ }^{13} \mathrm{C}-\mathrm{NMR}$ chemical shifts of 2-7 are in agreement with the values calculated with a theoretical program. In the ${ }^{1} \mathrm{H}-\mathrm{NMR}$ spectra, some NH groups were not clearly observed due to a rapid chemical exchange with the solvent; consequently, they are not reported in this work. The assignment of observed exchangeable hydrogens was confirmed by the addition of $\mathrm{D}_{2} \mathrm{O}$, which showed that the $\mathrm{NH}$ signals disappeared, and that the signal corresponding to the 5' $-\mathrm{OH}$ group in AZT ( $\delta$ 5.2) was not present in compounds 2-7, thus confirming the 5 '-OH substitution.

The ${ }^{1} \mathrm{H}-\mathrm{NMR}$ signals of $\mathbf{2}$ and $\mathbf{3}$ are in agreement with those of Lin et al. ${ }^{14}$ The chemical shifts of 4-7, corresponding to $\mathrm{CH}_{3}$-base, H-1', $\mathrm{H}-2$ ', $\mathrm{H}-3$ ' ' and H-6 at $\delta 1.73,6.05,2.27,4.35$ and 7.62 , respectively, also correlating with those of the AZT. ${ }^{18,22,23}$ On the other hand, the ${ }^{1} \mathrm{H}-\mathrm{NMR}$ spectra of 4-7 (also 2 ) showed an inversion in the chemical shifts of H-4' $(\delta c a .4 .05)$ and H-5' $(\delta c a .4 .29)$ signals with respect to those of AZT (H-4', $\delta 3.77$; H-5', $\delta$ 3.58 ), as we have observed for other AZT-derivatives. ${ }^{18,22}$ Hence, downfield chemical shifts with a displacement for $\mathrm{H}-5$ ' greater than for $\mathrm{H}-4$ ' were observed with a $\Delta \delta_{\mathrm{H}-5}, c a$. $0.71 ; \Delta \delta_{\mathrm{H}-4}, c a .0 .28,\left(\Delta \delta=\delta_{\text {AZT-derivative }}-\delta_{\mathrm{AZT}}\right)$, due to $\mathrm{H}-5$, being close to the carbonyl group.<smiles>Cc1cn([C@H]2C[C@H](C#N)[C@H](CO)O2)c(=O)[nH]c1=O</smiles>

AZT

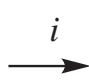

AZT-Py

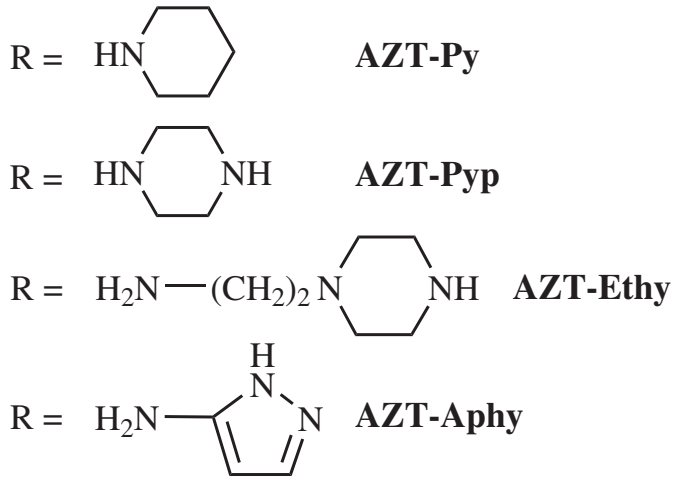<smiles></smiles>

AZT-CI<smiles>N#C[V]</smiles><smiles>[R]C(=O)OC[C@H]1O[C@@H]2C[C@H]([N])[C@H]1C2</smiles>

5'-O-carbamates of AZT

(i) $\mathrm{CDI} ; \mathrm{CH}_{3} \mathrm{CN}, \mathrm{N}_{2}, 40^{\circ} \mathrm{C}$, 5h. (ii) R-NH, $\mathrm{CH}_{3} \mathrm{CN}, \mathrm{N}_{2}, 40{ }^{\circ} \mathrm{C}$. 
The ${ }^{13} \mathrm{C}$-NMR assignments of compounds 2-7 were confirmed by using the $135^{\circ}$ DEPT and HETCOR $\left({ }^{1} \mathrm{H}-{ }^{13} \mathrm{C}\right)$ techniques, with the nucleoside carbons being assigned by analogy with those of AZT. ${ }^{18,22,23}$ The most characteristic ${ }^{13} \mathrm{C}-\mathrm{NMR}$ features for 4-7 are the chemical shifts for their acylic carbon atom, $\delta c a .154 .50$ corresponding to the $\mathrm{C}=\mathrm{O}$ carbon of carbamate moiety (C-1", Figure 1), which are not present in the spectra of AZT, 2 or $\mathbf{3}$. Compound $\mathbf{3}$ presented some differences in C-4 $(\delta$ 171.12), C-2 $(\delta$ 156.78) and C-5 ( $\delta$ 117.13) compared to those of AZT (C-4, $\delta$ 161.78; C-2, $\delta 148.48$ and C-5, $\delta$ 107.59), with downfield chemical shifts being observed, $\Delta \delta_{\mathrm{C}-4}=9.34 ; \Delta \delta_{\mathrm{C}-2}=8.3 ; \Delta \delta_{\mathrm{C}-5}=9.54$ $\left(\Delta \delta=\delta_{\text {AZT-derivative }}-\delta_{\text {AZT }}\right)$, due to the pyrimidinic base being affected by the formation of an additional ring. In addition, the C-5' signal ( $\delta=74.74)$ was also affected, with more downfield chemical shifts observed, compared with that of AZT $(\delta=58.90)(\Delta \delta=15.84)$.

In the IR spectra of 2-7 (KBr), absorptions at 2800 and $3100 \mathrm{~cm}^{-1}$ corresponding to $\mathrm{C}-\mathrm{H}$ stretchings are observed, as well as characteristic feature of these molecules at $2100 \mathrm{~cm}^{-1}$ due to the asymmetric stretchings of the azido group..$^{18,22,23}$ The absorption bands around $1700 \mathrm{~cm}^{-1}$ arose from $\mathrm{C}=\mathrm{O}$ and $\mathrm{N}-\mathrm{H}$ of the pyrimidinic amide group stretchings, as in the case of the carbamate group stretchings of 4-7, appear as a broad band for some compounds. In the IR spectrum of $\mathbf{3}$, the absorption bands at 1300 and $1000 \mathrm{~cm}^{-1}$ representing the C-O-C vibrations were much more complex and pronounced in this spectrum than in AZT. This absorption band was expected due to the additional cyclic ether group present in this structure. In compound 2, signals at 1367 and 1194 $\mathrm{cm}^{-1}$ correspond to asymmetric and symmetric stretchings of $\mathrm{S}(=\mathrm{O})_{2}$, respectively. For 5-7, bands around $3400 \mathrm{~cm}^{-1}$ were observed, corresponding to $\mathrm{NH}$ stretching of the cyclic secondary amines.
It is important to point out that the absorption bands at $3474 \mathrm{~cm}^{-1}$, corresponding to $\mathrm{OH}$ group in the AZT, were not found in 2-7.

\section{Antiviral activity}

Derivatives 2-7 were evaluated for their ability to inhibit in vitro replication of HIV-1 in PBMC cell culture. Two Selectivity Indexes, $\mathrm{SI}^{\mathrm{TB}}$ (Tripan Blue) and $\mathrm{SI}^{\mathrm{SRB}}$ (Sulforhodamine B) were calculated on the basis of their antiviral activity and cytotoxicity values, according to the methodologies employed to evaluate cytotoxicity, as mentioned in Experimental. The results are listed in Table 2.

Assays on infected and uninfected PBMCs showed cytotoxicity significantly lower than AZT for novel AZT derivatives, but a reduced antiretroviral activity. Derivatives $\mathbf{4}$ and $\mathbf{5}$ showed a reduced SI, mainly driven by their high $\mathrm{IC}_{50}$. Although derivatives $\mathbf{2 ,} \mathbf{6}$ and $\mathbf{7}$ did not show cytotoxicity within the concentration range tested, they were not able to inhibit HIV-1 replication even at a concentration 300-fold higher than AZT IC $\mathrm{I0}_{50}$. Similarly, 3 showed no cytotoxicity, but the $\mathrm{IC}_{50}$ obtained was more than 30-fold higher than that of AZT. These results indicate that although these AZT derivatives are less toxic than AZT, their reduced cytotoxicities are concomitant with a significant decrease to inhibit HIV-1 replication, except in the case of AZT-Cycl (3) which showed an $\mathrm{IC}_{50}=1 \mu \mathrm{mol} \mathrm{L}-1$ without cytotoxicity.

\section{Stability assays}

Enzymatic stability assays in plasma medium at $37^{\circ} \mathrm{C}$ showed that 2-6remained stable during all assay periods $(30 \mathrm{~h})$.

Table 2. Cytotoxicity, in vitro anti-HIV activity and selectivity indexes of the studied analogs of AZT

\begin{tabular}{|c|c|c|c|c|c|}
\hline \multirow[t]{2}{*}{ Compound } & \multicolumn{2}{|c|}{$\mathrm{CCID}_{50} /(\mu \mathrm{mol} \mathrm{L}-1)^{\mathrm{a}}$} & \multirow[t]{2}{*}{$\mathrm{IC}_{50} /\left(\mu \mathrm{mol} \mathrm{L} \mathrm{L}^{-1}\right)^{\mathrm{b}}$} & \multicolumn{2}{|c|}{$\mathrm{SI}^{\mathrm{c}}$} \\
\hline & $\mathrm{TB}^{\mathrm{d}}$ & $\mathrm{SRB}^{\mathrm{e}}$ & & TB & SRB \\
\hline AZT (1) & 10 & 400 & 0.03 & $333 \pm 56$ & $13,000 \pm 2,950$ \\
\hline AZT-Tos (2) & $\mathrm{Nd}$ & $>1000$ & $>10$ & nd & - \\
\hline AZT-Cycl (3) & $\mathrm{Nd}$ & $>1000$ & 1 & nd & $>1000$ \\
\hline AZT-Py (4) & 200 & nd & 10 & $20 \pm 1$ & nd \\
\hline AZT-Pyp (5) & 200 & nd & 10 & $20 \pm 1$ & nd \\
\hline AZT-Ethy (6) & $>1000$ & nd & $>10$ & -- & nd \\
\hline AZT-Aphy (7) & $>1000$ & nd & $>10$ & -- & nd \\
\hline
\end{tabular}

${ }^{\mathrm{a}} \mathrm{CCID}_{50}: 50 \%$ Cell Culture Inhibitory Dose, ${ }^{\mathrm{b}} \mathrm{IC}_{50}: 50 \%$ Inhibitory Concentration, ${ }^{\mathrm{c}} \mathrm{SI}$ : Selectivity index $\left(\mathrm{CCID}_{50} / \mathrm{IC}_{50}\right)$, ${ }^{\mathrm{d}} \mathrm{TB}:$ Tripan Blue dye, ${ }^{\mathrm{e}} \mathrm{SRB}$ : Sulforhodamine B dye, nd: not determined. 
Similarly; other drugs with carbamate moieties unions were also stable in plasma or cellular culture..$^{24,25}$

\section{Experimental}

Materials, apparatus and general procedures

AZT was generously supplied by Filaxis (Buenos Aires, Argentina). Tosyl chloride (Aldrich) was purified according to a previously described procedure, ${ }^{26}$ and 3 -aminopyrazole (Aldrich), piperazine, piperidine and 2-(1-piperazinyl) ethylamine (Merck) and $N, N^{\prime}$-carbonyldiimidazole (CDI, Sigma) were used without purification. All solvents used were of analytical grade. Dimethylformamide (DMF, Anedra) was dried with $4 \AA$ molecular sieves. Tetrahydrofurane (THF, Anedra) was dried with metallic sodium before distillation and $\mathrm{CH}_{3} \mathrm{CN}$ (grade HPLC, Sintorgan) was used without distillation. Analytical thin layer chromatography (TLC) was performed on percolated plates purchased from Merck (Silica Gel 60 $\mathrm{F}_{254}$ ). Column chromatography was performed on silica gel 60 (0.063-0.200 mm, Merck). ${ }^{1} \mathrm{H}$ and ${ }^{13} \mathrm{C}$-NMR spectra were recorded on a Bruker AC 200 spectrometer $(200.13 \mathrm{MHz})$, at $25^{\circ} \mathrm{C}$, using DMSO- $\mathrm{d}_{6}($ Merck) as the solvent. The assignment of all exchangeable protons $(\mathrm{OH}, \mathrm{NH})$ was confirmed by the addition of $\mathrm{D}_{2} \mathrm{O}$ (Sigma). Chemical shift values were reported in parts per million $(\delta)$ relative to tetramethylsilane (Sigma) as the internal standard, with informed coupling constants $(J)$ given in Hertz $(\mathrm{Hz})$. The splitting pattern abbreviations were as follows: s, singlet; $\mathrm{d}$, doublet; $\mathrm{t}$, triplet; $\mathrm{m}$, multiplet; dd, doublet of doublet; ddd, doublet of doublet of doublet; quad, quadruplet and q, quintuplet. All ${ }^{13} \mathrm{C}-\mathrm{NMR}$ spectra were proton-decoupled, and were confirmed by using the $135^{\circ} \mathrm{DEPT}$, as well as COSY and HETCOR. IR spectra were obtained from potassium bromide ( $\mathrm{KBr}$, Merck) disks on a Nicolet 5 SXC FT-IR. Ultraviolet spectrophotometric (UV) studies were carried out with a Shimadzu Model UV-160A spectrophotometer, using $1 \mathrm{~cm}$ quartz cells. Melting points were determined for differential scanning calorimetry analysis (DSC) using a 2920 modulated DSC (TA Instrument). HPLC analyses were carried out using an Agilent ${ }^{\circledR} 1100$ apparatus equipped with Phenomenex ${ }^{\circledR}$ column, Hypersil ODS $5 \mu$ particle diameter $(4.6 \times 250 \mathrm{~mm})$.

\section{Chemistry}

\section{3'-Azido-3',5'-dideoxythymidine-5'-tosylate (AZT-Tos, 2)}

3'-Azido-3'-deoxythymidine (AZT, 1, $267 \mathrm{mg}, 1 \mathrm{mmol}$ ) was dissolved in pyridine $(1 \mathrm{~mL})$, and the stirred mixture was cooled to $0{ }^{\circ} \mathrm{C}$. Tosyl chloride ( $381 \mathrm{mg}, 2 \mathrm{mmol}$ ) was then added, and the reaction mixture was maintained in these conditions for $8 \mathrm{~h}$. Then, the reaction was diluted with $\mathrm{CH}_{2} \mathrm{Cl}_{2}$
(20 mL), and washed with 2 aliquots of $15 \mathrm{~mL}$ of saturated $\mathrm{HCl}_{\mathrm{aq}}$. Phases were separated, and the organic layer was washed with 3 aliquots of $20 \mathrm{~mL}$ of distilled water, then dried over $\mathrm{Na}_{2} \mathrm{SO}_{4}$ and filtered. $\mathrm{CH}_{2} \mathrm{Cl}_{2}$ was then removed in vacuum to yield a solid. This was then purified by recrystallization from EtOH to give 2 as a light yellow solid. Yield: $336.8 \mathrm{mg}, 80 \%$; mp $116.2^{\circ} \mathrm{C}$. TLC system: $\mathrm{CH}_{2} \mathrm{Cl}_{2} / \mathrm{MeOH}(8: 1 \mathrm{v} / \mathrm{v}), \mathrm{R}_{\mathrm{f}}: 0.90$. $\mathrm{UV}\left(\mathrm{H}_{2} \mathrm{O}\right) \lambda_{\max } / \mathrm{nm}: 220$ and 265.8. IR $v_{\max } / \mathrm{cm}^{-1}: 3202,2140$, 1705, 1367, 1194. ${ }^{1} \mathrm{H}$ NMR (DMSO-d $)$ ): $\delta 11.41$ (s, 1H, NH-3), 7.89 (d, J 8.04 Hz, 2H, H-2", H-6"), 7.56 (d, J 8.04 Hz, 2H, H-3", H-5”), 7.47 (s, 1H, H-6), 6.16 (t, J 6.6 Hz, 1H, H-1'), 4.49 (dd, J 12.5 Hz; J 5.48 Hz 1H, H-3'), 4.37 (dd, J $6.22 \mathrm{~Hz}$; $J 4.00 \mathrm{~Hz}, 2 \mathrm{H}, \mathrm{H}-5{ }_{\mathrm{a}, \mathrm{b}}$ ), 4.03 (quad, $J 5.12 \mathrm{~Hz}, 1 \mathrm{H}, \mathrm{H}-4$ '), 2.50 (s, $\left.3 \mathrm{H}, \mathrm{CH}_{3}-\mathrm{C}_{6} \mathrm{H}_{4}\right), 2.28-2.66\left(\mathrm{~m}, 2 \mathrm{H}, \mathrm{H}-2{ }_{\mathrm{a}, \mathrm{b}}\right), 1.86\left(\mathrm{~s}, 3 \mathrm{H}, \mathrm{CH}_{3}-\right.$ 5). ${ }^{13} \mathrm{C}$ NMR (DMSO-d $)$ ): $\delta 163.71(\mathrm{CO}, \mathrm{C}-4), 150.42(\mathrm{CO}$, C-2), 145.33 (C, C-1"), 136.08 (CH, C-6), 132.15 (C, C-4"), 130.29, 127.75 (CH- Ar), 109.99 (C, C-5), 84.04, (CH, C-1'), 80.40 (CH, C-4'), $69.56\left(\mathrm{CH}_{2}, \mathrm{C}-5\right.$ '), 59.81 (CH, C-3'), 35.63 $\left(\mathrm{CH}_{2}, \mathrm{C}-2\right.$ '), $21.21\left(\mathrm{CH}_{3}, \mathrm{C}-7\right.$ '”), $12.15\left(\mathrm{CH}_{3}, \mathrm{C} 5\right)$.

\section{3'-Azido-O', 5' cyclothymidine (AZT-Cycl, 3)}

Anhydrous $\mathrm{Na}_{2} \mathrm{CO}_{3}$ (excess) was added to a solution of $2(250 \mathrm{mg}, 0.6 \mathrm{mmol})$ in dry DMF ( $1 \mathrm{~mL})$, and the mixture was refluxed for $24 \mathrm{~h}$ with stirring, with a total conversion of 2. The resulting filtrated mixture was extracted with $\mathrm{Cl}_{2} \mathrm{CH}_{2}$ and $\left(\mathrm{CH}_{3}\right)_{2} \mathrm{CO}$ and the organic layers were then combined. The solvents were removed in vacuum and the product was purified by column chromatography on silica gel, using as initial eluent $\mathrm{Cl}_{2} \mathrm{CH}_{2}$, followed by a gradient of solvent until a solution of EtOAc/ $\left(\mathrm{CH}_{3}\right)_{2} \mathrm{CO}(8: 2 \mathrm{v} / \mathrm{v})$. The appropriate fractions were combined, and the solvent was removed in vacuum to give 3 as a white solid. Yield: $74.7 \mathrm{mg}, 50 \%$; $\mathrm{mp}$ exothermic decomposition without melting. TLC system: $\mathrm{Cl}_{2} \mathrm{CH}_{2} / \mathrm{MeOH}(8: 1 \mathrm{v} / \mathrm{v}), \mathrm{R}_{\mathrm{f}}: 0.55$ and $\mathrm{C}_{6} \mathrm{H}_{6} / \mathrm{Cl}_{2} \mathrm{CH}_{2} / \mathrm{EtOH}$ $(9: 1: 3 \mathrm{v} / \mathrm{v}), \mathrm{R}_{\mathrm{F}}: 0.35$. UV $\left(\mathrm{H}_{2} \mathrm{O}\right) \lambda_{\max } / \mathrm{nm:} 204$ and 250. IR $v_{\max } / \mathrm{cm}^{-1}: 2096,1673,1291,1275,1087 .{ }^{1} \mathrm{H}$ NMR (DMSO-d $)$ ): $\delta 7.85$ (s, 1H, H-6), 6.13 (dd, $J 7.67 \mathrm{~Hz}, J 1.83$, Hz, 1H, H-1'), 4.70-4.59 (m, 2H, H-4', H-3'), 4.63 (d, J 12.40 $\left.\mathrm{Hz}, J 1.82 \mathrm{~Hz}, 1 \mathrm{H}, \mathrm{H}-5{ }_{\mathrm{a}}\right), 4.18$ (d, J $12.42 \mathrm{~Hz}, 1 \mathrm{H}, \mathrm{H}-5{ }_{\mathrm{b}}$ ), 2.73 (ddd, $J 15.55 \mathrm{~Hz}, J 7.68 \mathrm{~Hz}, J 1.82 \mathrm{~Hz}, 1 \mathrm{H}, \mathrm{H}-2_{\mathrm{b}}{ }_{\mathrm{b}}$ ), 2.54 (ddd, $J 15.55 \mathrm{~Hz}, J 7.68 \mathrm{~Hz}, J 1.82 \mathrm{~Hz}, 1 \mathrm{H}, \mathrm{H}-2{ }^{\prime}{ }_{\mathrm{a}}$ ), 1.87 (s, $\left.3 \mathrm{H}, \mathrm{CH}_{3}-5\right) .{ }^{13} \mathrm{C}$ NMR (DMSO-d $): \delta 171.12$ (CO, C-4), 156.78 (CO, C-2), 139.21 (CH, C-6), 117.13 (C, C-5), 92.58 (CH, C-1'), $83.82\left(\mathrm{CH}, \mathrm{C}-4\right.$ '), $74.74\left(\mathrm{CH}_{2}, \mathrm{C}-5\right.$ '), $61.95(\mathrm{CH}$, C-3'), $39.56\left(\mathrm{CH}_{2}, \mathrm{C}-2^{\prime}\right), 13.07\left(\mathrm{CH}_{3}-\mathrm{C} 5\right)$.

General procedure for the synthesis of carbamate compounds (4-7)

CDI (324 mg, $2 \mathrm{mmol}$ ) was added to a solution of AZT (267 mg, $1 \mathrm{mmol}$ ) in anhydrous $\mathrm{CH}_{3} \mathrm{CN}$ under $\mathrm{N}_{2}$. The 
reaction mixture was then stirred at $40{ }^{\circ} \mathrm{C}$ for $5 \mathrm{~h}$, and the progress of the reaction was monitored by TLC (EtOAc/ petroleum ether/ $\left.\left(\mathrm{CH}_{3}\right)_{2} \mathrm{CO}, 7: 3: 4 \mathrm{v} / \mathrm{v}\right)$. Afterwards, the amine compound was added, and the reaction mixture was maintained in the same conditions until total conversion was achieved of the intermediate of AZT (AZT-CI) with the formation of the corresponding carbamate product, TLC system: $\mathrm{Cl}_{2} \mathrm{CH}_{2} / \mathrm{MeOH}(8: 1 \mathrm{v} / \mathrm{v})$. For compound 4, the solvent was removed under reduced pressure and the residual oil was dissolved in $\mathrm{CH}_{2} \mathrm{Cl}_{2}$. The organic phase was successively washed with water, dried over $\mathrm{Na}_{2} \mathrm{SO}_{4}$, filtered, and the solvent removed in vacuum. Compound 4 was crystallized by solvent change from EtOAc-hexane. For compounds 5-7, the solvent was removed under reduced pressure and the residual oil successively washed with $\left(\mathrm{C}_{2} \mathrm{H}_{5}\right)_{2} \mathrm{O}$. Evaporation of the solvent gave a crude product, which was then purified by column chromatography on silica gel using initial eluent of EtOAc followed by a gradient of solvent until a solution of $\left(\mathrm{CH}_{3}\right)_{2} \mathrm{CO} / \mathrm{MeOH}$ $(8: 2 \mathrm{v} / \mathrm{v})$. The appropriate fractions were then combined and the solvent removed in vacuum.

\section{3'-Azido-3'-deoxythymidin-5'-yl-N-[piperidine] carbamate (AZT-Py, 4)}

The general procedure described above, using piperidine $(0.2 \mathrm{~mL}, 2 \mathrm{mmol})$ in $\mathrm{CH}_{3} \mathrm{CN}(8 \mathrm{~mL})$, afforded compound 4 as a white solid. Yield: $310 \mathrm{mg}, 82 \%$; mp 114.3 ${ }^{\circ} \mathrm{C}$. $\mathrm{R}_{\mathrm{f}}: 0.64$. UV $\left(\mathrm{H}_{2} \mathrm{O}\right) \lambda_{\max } / \mathrm{nm}: 207.4$ and 267.2. IR $v_{\max } / \mathrm{cm}^{-1}: 2111,1698 .{ }^{1} \mathrm{H}$ NMR (DMSO-d $\left.\mathrm{d}_{6}\right): \delta 11.30$ (s, 1H, NH-3), 7.52 (s, 1H, H-6), 6.19 (t, J $6.6 \mathrm{~Hz}, 1 \mathrm{H}$, H-1'), 4.55 (ddd, $J 12.78 \mathrm{~Hz}, J 12.42 \mathrm{~Hz}, J 6.02 \mathrm{~Hz}, 1 \mathrm{H}$, H-3'), 4.32 (dd, J $4.38 \mathrm{~Hz}, J 4.02 \mathrm{~Hz}, 2 \mathrm{H}, \mathrm{H}-5{ }^{\prime}{ }_{\mathrm{a}, \mathrm{b}}$ ), 4.06 (dd, J 9.87, J 4.76 Hz, 1H, H-4'), 3.32-3.48 (m, 4H, H-2', H-6"), 2.47 (ddd, J $12.78 \mathrm{~Hz}, J 12.42 \mathrm{~Hz}, J 6.04 \mathrm{~Hz}, 2 \mathrm{H}$, $\mathrm{H}-2$ ' ${ }_{\mathrm{ab}}$ ), 1.88 (s, 3H, $\left.\mathrm{CH}_{3}-5\right), 1.60-1.52$ (m, 6H, H-3", H-4", H-5"). ${ }^{13} \mathrm{C}$ NMR (DMSO-d $): \delta 163.76$ (CO, C-4), 154.25 (CO, C-1"), 150.47 (CO, C-2), 136.0 (CH, C-6), 109.99 (C, C-5), $83.71\left(\mathrm{CH}, \mathrm{C}-1\right.$ '), $81.02\left(\mathrm{CH}, \mathrm{C}-4\right.$ '), $64.15\left(\mathrm{CH}_{2}\right.$, C-5'), 60.29 (CH, C-3'), 44.50 ( $\mathrm{CH}_{2}, \mathrm{C}-3$ '”, C-7”'), 35.85 $\left(\mathrm{CH}_{2}, \mathrm{C}-2\right.$ '), $25.36\left(\mathrm{CH}_{2}, \mathrm{C}-4\right.$ ", $\mathrm{C}-6$ ") $), 23.83\left(\mathrm{CH}_{2}, \mathrm{C}-5\right.$ "), $12.21\left(\mathrm{CH}_{3}-\mathrm{C} 5\right)$.

\section{3'-Azido-3'-deoxythymidin-5'-yl-N-[piperazine] carbamate (AZT-Pyp, 5)}

The general procedure described above, using piperazine (129 mg, $1.5 \mathrm{mmol}$ ) in $\mathrm{CH}_{3} \mathrm{CN}(8 \mathrm{~mL})$, afforded compound 5 as a yellow solid. Yield: $269 \mathrm{mg}, 71 \%$; mp exothermic decomposition without melting. $\mathrm{R}_{\mathrm{f}}: 0.38$. UV $\left(\mathrm{H}_{2} \mathrm{O}\right) \lambda_{\max } / \mathrm{nm}: 210$ and 266.4. IR $v_{\max } / \mathrm{cm}^{-1}: 3420,2106$, 1698. ${ }^{1} \mathrm{H}$ NMR (DMSO-d $)$ ): $\delta 7.51$ (s, 1H, H-6), 6.19 (t, $J 6.6 \mathrm{~Hz}, 1 \mathrm{H}, \mathrm{H}-1$ '), 4.56 (dd, J $12.78 \mathrm{~Hz}, J 6.22 \mathrm{~Hz}, 1 \mathrm{H}$,
H-3'), 4.29 (dd, J $12.07 \mathrm{~Hz}, J 4.38 \mathrm{~Hz}, 1 \mathrm{H}, \mathrm{H}-5^{\prime}{ }_{\mathrm{a}}$ ), 4.21 (dd, $J 12.07 \mathrm{~Hz}, J 5.12 \mathrm{~Hz}, 1 \mathrm{H}, \mathrm{H}-5^{\prime}{ }_{\mathrm{b}}$ ), 4.06 (dd, $J 10.28$ $\mathrm{Hz}, J 5.48 \mathrm{~Hz}, 1 \mathrm{H}, \mathrm{H}-4$ '), 3.38 (dd, J $4.74 \mathrm{~Hz}, J 4.38 \mathrm{~Hz}$, 4H, H-2", H-6"), 2.72 (dd, J $4.76 \mathrm{~Hz}, J 4.38 \mathrm{~Hz}, 4 \mathrm{H}$, H-3", H-5"), 2.47 (dd, J $12.60 \mathrm{~Hz}, J 6.00 \mathrm{~Hz}, 2 \mathrm{H}, \mathrm{H}-2$ ' ${ }_{\mathrm{abb}}$ ), $1.88\left(\mathrm{~s}, 3 \mathrm{H}, \mathrm{CH}_{3}-5\right) .{ }^{13} \mathrm{C}$ NMR (DMSO-d $\left.\mathrm{d}_{6}\right): \delta 163.82(\mathrm{CO}$, C-4), 154.38 (CO, C-1"), 150.50 (CO, C-2), 136.03 (CH, C-6), 110.02 (C, C-5), 83.74 ( $\mathrm{CH}, \mathrm{C}-1^{\prime}$ ), 81.02 (CH, C-4'), $64.18\left(\mathrm{CH}_{2}, \mathrm{C}-5\right.$ ') 60.26 (CH, C-3'), $45.47\left(\mathrm{CH}_{2}, \mathrm{C}-4\right.$ "', C-6"), $44.85\left(\mathrm{CH}_{2}, \mathrm{C}-3\right.$ ", C-7"), $35.88\left(\mathrm{CH}_{2}, \mathrm{C}-2\right.$ '), 12.24 $\left(\mathrm{CH}_{3}-\mathrm{C} 5\right)$.

\section{3'-Azido-3'-deoxythymidin-5'-yl-N-[ethylpiperazine] carbamate (AZT-Ethy, 6)}

The general procedure described above, using 2-(1-piperazinyl)ethylamine $(0.193 \mathrm{~mL}, 1.5 \mathrm{mmol})$ in $\mathrm{CH}_{3} \mathrm{CN}(10 \mathrm{~mL})$, afforded compound $\mathbf{6}$ as an orange solid. Yield: $308 \mathrm{mg}$, 73\%; mp exothermic decomposition without melting. $\mathrm{R}_{\mathrm{f}}: 0.10$. UV $\left(\mathrm{H}_{2} \mathrm{O}\right) \lambda_{\max } / \mathrm{nm}: 207.4$ and 266.6. IR $\mathrm{v}_{\max } / \mathrm{cm}^{-1}: 3440,2106,1709 .{ }^{1} \mathrm{H} N M R\left(D M S O-\mathrm{d}_{6}\right): \delta 8.52(\mathrm{br}$, $1 \mathrm{~N}, \mathrm{NH}-3) \delta 7.52$ (s, 1H, H-6), 7.12-7.22 (m, 1H, NH-2"), 6.20 (t, J 6.6 Hz, 1H, H-1'), 4.52-4-40 (m, 1H, H-3'), 4.25 (dd, J $11.68 \mathrm{~Hz}, J 3.50 \mathrm{~Hz}, 1 \mathrm{H}, \mathrm{H}-5^{\prime}{ }_{\mathrm{a}}$ ), 4.07 (dd, J $11.70 \mathrm{~Hz}$, $J$ 5.10 Hz, 1H, H-5 ${ }_{\mathrm{b}}$ ), 4.02-3.98 (m, 1H, H-4'), 3.19 (dd, $J 12.6 \mathrm{~Hz}, J 6.4 \mathrm{~Hz}, 2 \mathrm{H}, \mathrm{H}-3$ "), 2.80-2.66 (m, 4H, H-7", H-9"), 2.50-2.27 (m, 8H, H-2' ${ }_{\mathrm{a}, \mathrm{b}}$, H-4", H-6", H-10"), 1.88 (s, $\left.3 \mathrm{H}, \mathrm{CH}_{3}-5\right) .{ }^{13} \mathrm{C}$ NMR (DMSO-d 6 ): $\delta 163.79(\mathrm{CO}$, C-4), 155.89 (CO, C-1"), 150.53 (CO, C-2), $136.03(\mathrm{CH}$, C-6), 109.96 (C, C-5), 83.74 (CH, C-1'), 81.31 (CH, C-4'), $63.85\left(\mathrm{CH}_{2}, \mathrm{C}-5\right.$ '), 60.83 (CH, C-3'), $58.14\left(\mathrm{CH}_{2}, \mathrm{C}-4\right.$ '), $54.28\left(\mathrm{CH}_{2}, \mathrm{C}-6\right.$ ", C-10"), $45.60\left(\mathrm{CH}_{2}, \mathrm{C}-7\right.$ ", C-9"), 37.84 $\left(\mathrm{CH}_{2}, \mathrm{C}-3\right.$ " $), 35.68\left(\mathrm{CH}_{2}, \mathrm{C}-2\right), 12.26\left(\mathrm{CH}_{3}-\mathrm{C} 5\right)$.

\section{3'-Azido-3'-deoxythymidin-5'-yl-N-[3-aminopyrazole] carbamate (AZT-Aphy, 7)}

The general procedure described above, using 3-aminopyrazole (166 mg, $2 \mathrm{mmol})$ in $\mathrm{CH}_{3} \mathrm{CN}(9 \mathrm{~mL})$, afforded compound 7 as a white solid. Yield: $38 \mathrm{mg}, 11 \%$; mp 148-152 ${ }^{\circ} \mathrm{C} . \mathrm{R}_{\mathrm{f}}: 0.60$. UV $\left(\mathrm{H}_{2} \mathrm{O}\right) \lambda_{\max } / \mathrm{nm}: 207.4$ and 266.2. IR $v_{\max } / \mathrm{cm}^{-1}: 2096,1750 .{ }^{1} \mathrm{H}$ NMR (DMSO-d 6 ): $\delta 11.5$ (br, NH-3), 10.02 (br s, 2H, NH-2", NH-4"), 7.51 (d, J $2.2 \mathrm{~Hz}, 1 \mathrm{H}, \mathrm{H}-6$ "), 7.40 (s, 1H, H-6), 6.22 (s, 1H, H-7'), 6.09 (t, $J 6.6 \mathrm{~Hz}, 1 \mathrm{H}, \mathrm{H}-1$ '), 4.44 (q, J 3.29, 1H, H-3'), 4.29 (dd, J $12.06 \mathrm{~Hz}, J 2.92 \mathrm{~Hz}, 1 \mathrm{H}, \mathrm{H}-5{ }_{\mathrm{a}}$ ), 4.15 (dd, $J 11.88 \mathrm{~Hz}, J 4.02 \mathrm{~Hz}, 1 \mathrm{H}, \mathrm{H}-5{ }_{\mathrm{b}}$ ), 4.02 (quad, $J 3.29$ Hz 1H, H-4'), 2.51 (ddd, J $13.63 \mathrm{~Hz}, J 6.20 \mathrm{~Hz}, J 4.02 \mathrm{~Hz}$, $1 \mathrm{H}, \mathrm{H}-2$ ' $), 2.22$ (ddd, $J 13.63 \mathrm{~Hz}, J 6.20 \mathrm{~Hz}, J 4.02 \mathrm{~Hz}$, $\left.1 \mathrm{H}, \mathrm{H}-2{ }_{\mathrm{b}}\right), 1.66$ (s, $\left.3 \mathrm{H}, \mathrm{CH}_{3}-5\right) .{ }^{13} \mathrm{C}$ NMR (DMSO-d $)$ ): $\delta$ 163.82 (CO, C-4), 153.41 (CO, C-1"), 150.61 (CO, C-2), 146.97 (C, C-3"), 136.00 (CH, C-6), 129.24 (CH, C-6"), 110.02 (C, C-5), 95.28 (CH, C-7”), 83.74 (CH, C-1'), 
$81.31\left(\mathrm{CH}, \mathrm{C}-4\right.$ '), $64.31\left(\mathrm{CH}_{2}, \mathrm{C}-5\right.$ '), 61.07 (CH, C-3'), $35.66\left(\mathrm{CH}_{2}, \mathrm{C}-2\right), 12.21\left(\mathrm{CH}_{3}-\mathrm{C} 5\right)$.

\section{Cells and HIV-1 strain}

Peripheral Blood Mononuclear Cells (PBMC) were isolated by Ficoll-Hypaque (Amersham Pharmacia Biotech, Sweden) gradient centrifugation from peripheral blood of HIV-1 seronegative patients, stimulated with $0.1 \%$ phytohaemaglutinin (PHA) for three days and cultured at $37^{\circ} \mathrm{C}$ in RPMI-1640 medium (Sigma-Aldrich, USA) supplemented with 2 mmol L-glutamine (Gibco BRL, USA), $100 \mathrm{U} \mathrm{mL}^{-1}$ penicillin (Gibco BRL, USA), $100 \mu \mathrm{g} \mathrm{mL}^{-1}$ streptomycin (Gibco BRL, USA) and 10\% fetal calf serum (FCS, Gibco BRL, USA) plus $10 \mathrm{U} \mathrm{mL}^{-1}$ interleukin-2 (IL-2). The stock of HTLV-IIIB strain of HIV-1 was derived from chronically infected $\mathrm{H} 9$ cells and used in all assays described in this study.

\section{Antiviral activity and cytotoxicity assays}

PBMCs were infected with $6.45 \times 10^{5} \mathrm{TCID}_{50} / 10^{6}$ cells for $2 \mathrm{~h}$ at $37^{\circ} \mathrm{C}$. After infection, cells were washed and dispensed in a 96-well plate in the presence of various drug concentrations. The experiments were performed in triplicate, and wells treated with AZT were also monitored as controls of antiviral activity. The culture medium was changed at day 4 , but maintaining the original concentration of drug. On the seventh day, supernatant fluids were collected and the production of p24 antigen was subsequently evaluated through a commercial ELISA assay (ABBOT Laboratories, USA). The dose that inhibited $50 \%$ of the viral production $\left(\mathrm{IC}_{50}\right)$ was determined on the basis of $\mathrm{p} 24$ assays.

At the same time, cytotoxicity studies were performed on uninfected PBMCs in order to determine the concentration of drug that inhibited $50 \%$ of cell growth $\left(\mathrm{CCID}_{50}\right)$. Two different methodologies were used to evaluate the viability of the cells: Tripan Blue (TB) dye and the subsequent counting of viable cells in the Neubauer chamber and Sulforhodamine B (SRB) dye. ${ }^{27,28}$ Briefly, the latter methodology consists of fixing cells with TCA (trichloroacetic acid) $80 \%$, dyeing the fixed cells with SRB, and measuring the optical density at $492 \mathrm{~nm}$. Assays were performed in triplicate or quadruplicate when using the TB method or SRB method, respectively. Once both parameters $\left(\mathrm{CCID}_{50}\right.$ and $\left.\mathrm{IC}_{50}\right)$ had been obtained, the Selectivity Index (SI), defined as $\mathrm{CCID}_{50} / \mathrm{IC}_{50}$, was determined.

\section{Enzymatic stability}

Enzymatic stability assays of 2-7 were carried out in plasma, for $30 \mathrm{~h}$ at $37^{\circ} \mathrm{C}$. Evaluation of the corresponding samples was conducted in triplicate using solid-phase extraction methodology, ${ }^{29}$ followed by high performance liquid chromatography (HPLC) technique. For all compounds, identification of the parent compounds and AZT as a degradation product was performed by HPLC by comparing their HPLC retention times with those of authentic samples. Three solvent systems A (Buffer pH 7.5/ $\mathrm{CH}_{3} \mathrm{OH} / \mathrm{THF}$ (50:50:2 v/v) (Both grade HPLC, Sintorgan), $\mathrm{B}$ (Buffer $\mathrm{pH} 7.5 / \mathrm{CH}_{3} \mathrm{OH} / \mathrm{THF}$ (60:40:2 v/v) and C (Buffer $\mathrm{pH}$ 7.5/ $\mathrm{CH}_{3} \mathrm{OH} / \mathrm{THF}(65: 35: 2 \mathrm{v} / \mathrm{v})$ were used in order to obtain an optimal separation of the compound peaks studied. Thus, for solvent system A peak retention time $\left(t_{R}\right)$ was $3.5 \min$ for $\mathbf{1}, 12.6 \min$ for $\mathbf{2}$ and $10.8 \min$ for $\mathbf{4}$; for solvent system $B, t_{R}$ was 4 min for $\mathbf{1}, 4.8$ min for $\mathbf{5}$ and $5.2 \mathrm{~min}$ for $\mathbf{6}$ and for solvent system $\mathrm{C}, \mathrm{t}_{\mathrm{R}}$ was $5 \mathrm{~min}$ for $\mathbf{1}$ and $3.6 \mathrm{~min}$ for $\mathbf{3}$.

\section{Conclusions}

Different strategies were developed for the synthesis of 2-7, all of which included molecular modifications of the 5'-OH group of AZT, characterized by different spectroscopic methods.

Overall, the modifications introduced to the AZT molecule resulted in a decrease in cellular toxicity although the capacity of $\mathbf{2}$ and 4-7 to inhibit HIV-1 replication was also severely compromised. It should be noted that the enzymatic stability of 2-7 in plasma showed that these compounds remain unchanged during all stability assays $(30 \mathrm{~h})$. In addition, taking into account that the activity of AZT is mediated through AZT-triphosphate, and that the high stability of 2-7 the blocking groups cannot be removed intracellularly to give AZT, they have no chance of antiHIV activity. For this reason, these compounds cannot be considered as classical AZT prodrugs, due to an inadequate or slow breakdown of the 5'-carbamate moieties, and then their anti-HIV activity remains unclear.

Although compound 3 is almost 30 -fold less active than AZT, an absence of toxicity with a CCID $_{50}>1000 \mu \mathrm{mol} \mathrm{L}^{-1}$ was observed, thus rendered as a possible candidate for preclinical assays, such as pharmacokinetic and biodisponibility studies. Thus the antiviral mechanism of $\mathbf{3}$ suggests that this compound could be different from that of other AZT prodrugs.

Partition coefficients of 2-7, with exception of $\mathbf{3}$ and 4, have shown that these compounds are more lipophilic than AZT. ${ }^{30}$ No correlation between in vitro antiviral potency of 2-7 and their lipophilicity was observed. This feature means that cell permeability by passive diffusion mechanism is not the key for the biological activity of these compounds. 


\section{Acknowledgments}

The authors gratefully acknowledge Secretaría de Ciencia y Técnica de la Universidad Nacional de Córdoba (SECYT-UNC), Consejo Nacional de Investigaciones Científicas y Tecnológicas (CONICET) and Agencia Nacional de Promoción Científica y Tecnológica (FONCYT) of Argentina for financial support. The authors would also like to thank L. Alassia (FILAXIS Laboratories, Buenos Aires, Argentina) for supplying zidovudina. M.A.R. acknowledges receipt of fellowships granted by SECyTUNC and CONICET. Gloria Bonetto's assistance in NMR data analyses is also gratefully acknowledged.

\section{Supplementary Information}

Supplementary data are available free of charge at http://jbcs.sbq.org.br, as PDF file.

\section{References}

1. De Clercq, E.; Verh. K. Acad. Geneeskd. Belg. 2007, 69, 81.

2. Volsky, D. J.; Sakai, K.; Stevenson, M.; Dewhurst, S.; AIDS Res. 1986, Suppl 1, S35.

3. Mitsuya, H.; Weihold, K. J.; Furman, P. A.; Clain, M. H.; Nusinoff-Lehrman, S.; Gallo, R. C.; Bolognesi, D. P.; Barry, D. W.; Broder, S.; Proc. Natl. Acad. Sci. U. S. A. 1985, 82, 7096.

4. Furman, P. A.; Fyfe, J. A.; Clair, M. H.; Weinhold, K.; Rideout, J. L.; Freeman, G. A.; Nusinoff-Lehrman, S.; Bolognesi, D. P.; Broder, S.; Mitsuya, H.; Barry, D. W.; Proc. Natl. Acad. Sci. U. S. A. 1986, 83, 8333 .

5. Gill, P. S.; Rarick, M.; Brynes, R. F.; Cauey, D.; Loureiro, C.; Levine, A. M.; Ann. Intern. Med. 1987, 107, 502.

6. Chariot, P.; Drogou, I.; Lacroix-Szmania, I.; Eliezer-Vanerot, M. C.; Chazaud, B.; Lombes, A.; Schaeffer, A.; Zafrani, E. S.; J. Hepatol. 1999, 30, 156.

7. Groothuis, D. R.; Levy, R. M.; J. Neurovirol. 1997, 3, 387.

8. Anderson, P. L.; Kakuda, T. N.; Fletcher, C. V. In Pharmacotherapy: A Pathophysiologic Approach; DiPiro, J. T.; Talbert, R. L.; Yee, G. C.; Matzke, G. R.; Wells, B. G.; Posey, L. M. eds.; McGraw Hills Publishers: Australia, $7^{\text {th }}$ ed, 2008, ch 129

9. Pan-Zhou, X. R.; Cretton-Scott, E.; Zhou, X. J.; Yang, M. X.; Lasker, J. M.; Sommadossi, J. P.; Biochem. Pharmacol. 1998, $55,757$.
10. Clavel, F.; Hance, A. J.; N. Engl. J. Med. 2004, 350, 1023.

11. Mansky, L. M.; Bernard, L. C.; J. Virol. 2000, 74, 9532.

12. Parang, K.; Wiebe, L. I.; Knaus, E. E.; Curr. Med. Chem. 2000, 7, 995.

13 Sriram, D.; Srichakravarthy, N.; Bal, T. R.; Yogeeswari, P.; Biomed. Pharmacother. 2005, 59, 452.

14. Lin, T. S.; Shen, Z. Y.; August, E. M.; Brankovan, V.; Yang, H.; Ghazzouli, I.; Prusoff, W. H.; J. Med. Chem. 1989, 32, 1891.

15. Bondavalli, F.; Bruno, O.; Ranise, A.; Schenone, P.; Russo, S.; Loffreda, A.; de Novellis, V.; Lo Sasso, C.; Marmo, E.; Il Farmaco 1988, 12, 1019.

16. Sakthivel, K.; Krishna Kumar, R.; Pathak, T.; Tetrahedron 1993, 49, 4365.

17. Michelson, A. M.; Todd, A. R.; J. Chem. Soc. 1955, Part I, 816.

18. Baumgartner, M. T.; Motura, M. I.; Contreras, R. H.; Pierini, A. B.; Briñón, M. C.; Nucleosides, Nucleotides Nucleic Acids 2003, 22, 45.

19. Staab, H. A.; Angew. Chem. Int. Ed. Engl. 1962, 1, 351.

20. Rannard, S. P.; Davis, N. J; Org. Lett. 1999, 1, 993.

21. Rannard, S. P.; Davis, N. J.; Org. Lett. 2000, 2, 2117.

22. Moroni, G. N.; Bogdanov, P. M.; Briñón, M. C.; Nucleos. Nucleot. 2002, 21, 231.

23. Motura, M. I.; Moroni, G. N.; Teijeiro, S. A.; Salomón, H.; Briñón, M. C.; Nucleosides, Nucleotides Nucleic Acids 2002, 21, 217.

24. Vlieghe, P.; Bihel, F.; Clerc, T.; Pannecouque, C.; Witvrouw, M.; De Clercq, E.; Salles, J. P.; Cherman, J. C.; Kraus, J. L.; J. Med. Chem. 2001, 44, 777.

25. Anastasi, C.; Vlieghe, P.; Hantz, O.; Schorr, O.; Pannecouque, C.; Witvrouw, M.; de Clercq, E.; Clayatte, P.; DereuddreBosquet, N.; Dormont, D.; Gondois-Rey, F.; Hirsch, I.; Kraus, J. L.; Bioorg. Med. Chem. Lett. 2003, 13, 2459.

26. Perrin, D. D.; Armango, W. L.; Purification of Laboratory Chemicals, Butterworth Heinemann: Great Britain, 1988.

27. Skehan, P.; Storeng, R.; Scudiero, D.; Monks, A.; McMahon, J.; Vistica, D.; Warren, J.; Bokesch, H.; Kenney, S.; Boyd, M. R.; J. Natl. Cancer Inst. 1990, 82, 1107.

28. Turk, G.; Moroni, G. N.; Pampuro, S.; Briñón, M. C.; Salomón, H.; Int. J. Antimicrob. Agents 2002, 20, 282.

29. Quevedo, M. A.; Teijeiro, S. A.; Briñón, M. C.; Anal. Bioanal. Chem. 2006, 385, 377.

30. Raviolo, M. A.; Briñón, M. C.; J. Liq. Chromatogr. Relat. Technol. 2005, 28, 2195.

Received: December 1, 2008 Web Release Date: November 12, 2009 


\section{Synthesis and Antiretroviral Evaluation of Derivatives of Zidovudine}

\section{Mónica A. Raviolo, ${ }^{a}$ Juan S. Trinchero-Hernández, ${ }^{b}$ Gabriela Turk ${ }^{b}$ and Margarita C. Briñón*,a}

${ }^{a}$ Departamento de Farmacia, Facultad de Ciencias Químicas, Ciudad Universitaria, Universidad Nacional de Córdoba, 5000 Córdoba, Argentina

${ }^{b}$ Centro Nacional de Referencia para el SIDA, Departamento de Microbiología,

Facultad de Medicina, Universidad de Buenos Aires, Buenos Aires, Argentina
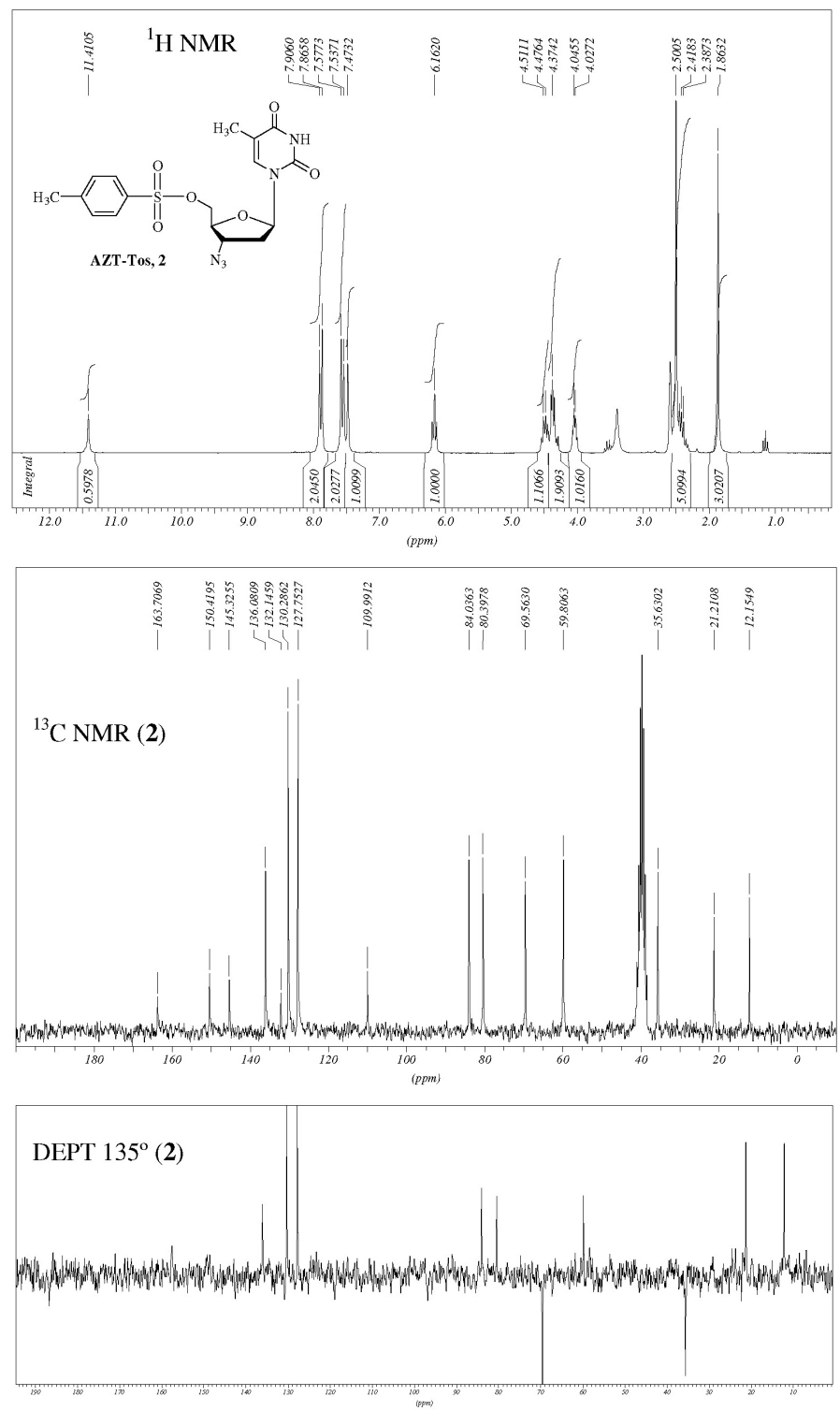

Figure S1a. ${ }^{1} \mathrm{H}$ NMR, ${ }^{13} \mathrm{C}$ NMR, DEPT $135^{\circ}$ of $2\left(200 \mathrm{MHz}\right.$, DMSO-d $\left.\mathrm{d}_{6}\right)$. 

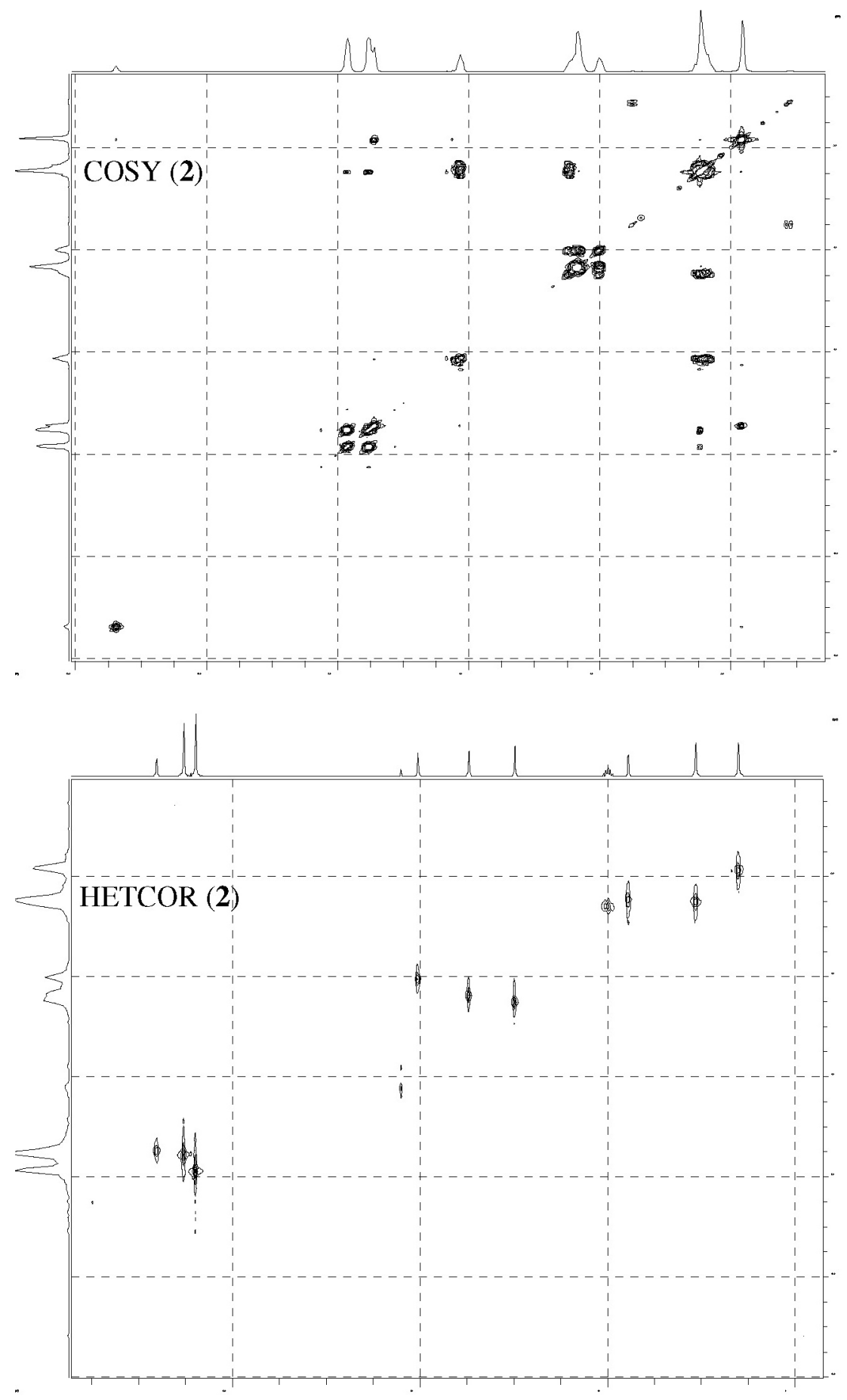

Figure S1b. COSY and HETCOR of 2 (200 MHz, DMSO-d $\left.{ }_{6}\right)$. 

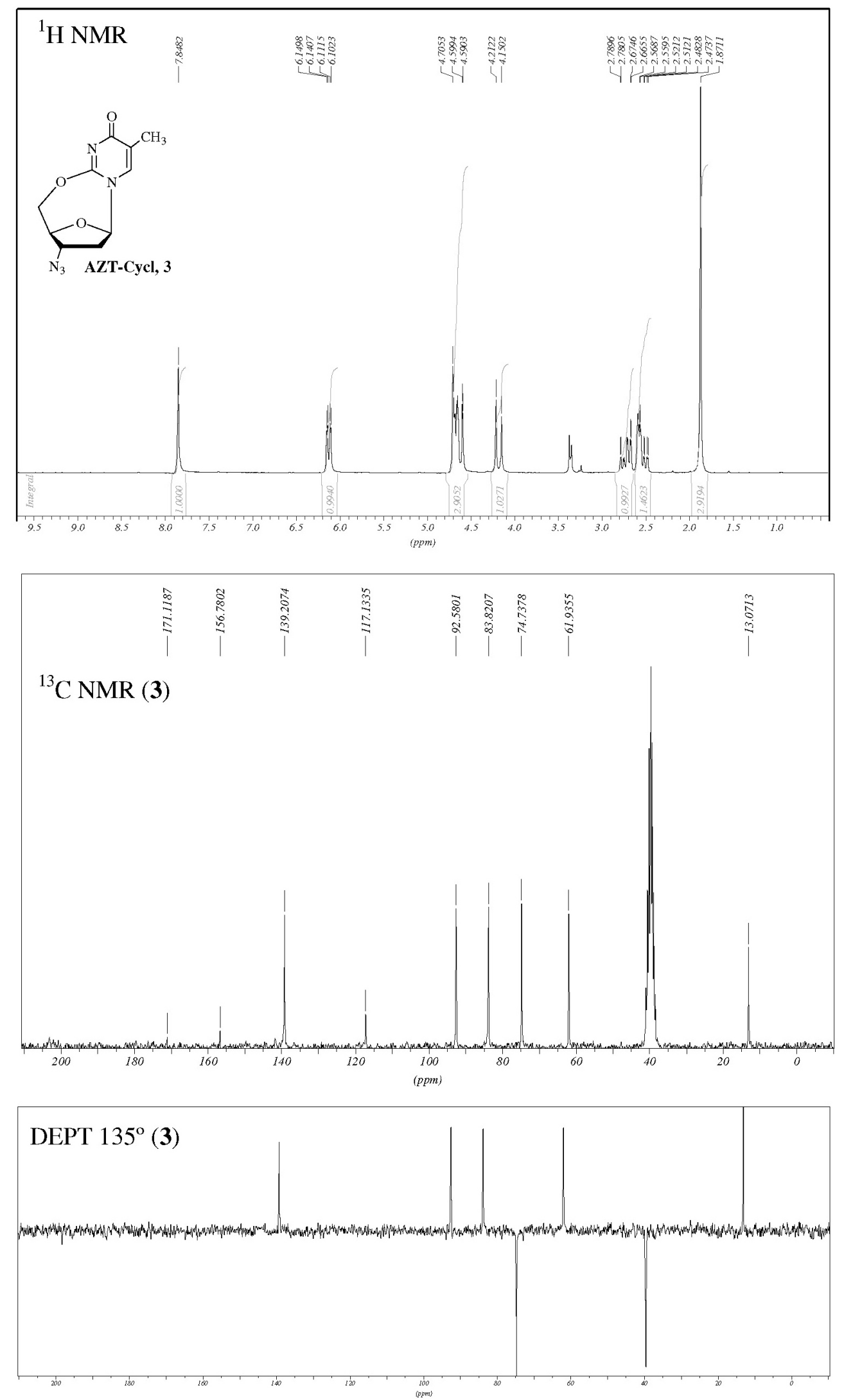

Figure S2a. ${ }^{1} \mathrm{H}$ NMR, ${ }^{13} \mathrm{C}$ NMR, DEPT $135^{\circ}$ of 3 (200 MHz, DMSO-d $)$. 

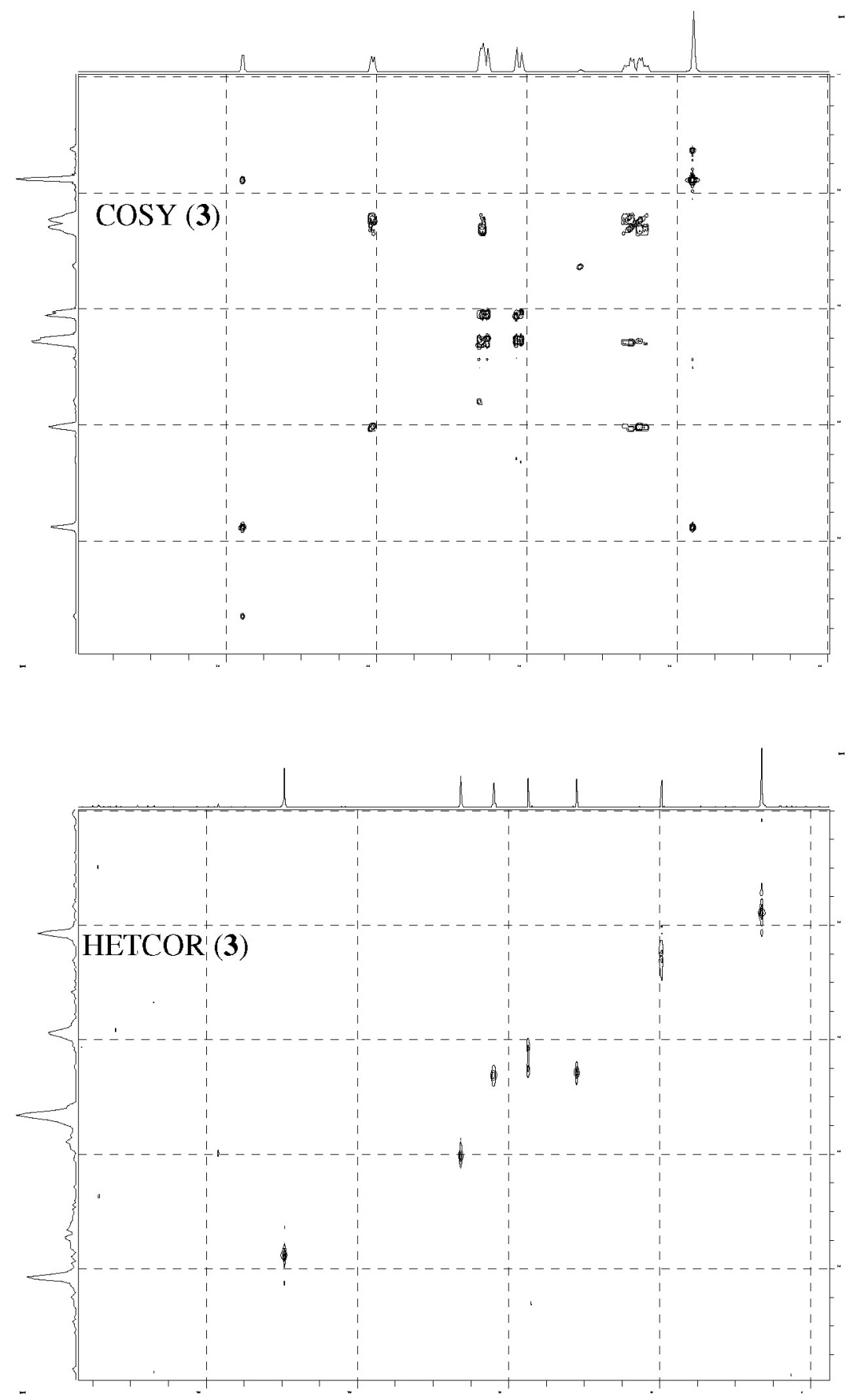

Figure S2b. COSY and HETCOR of 3 (200 MHz, DMSO-d ${ }_{6}$ ). 

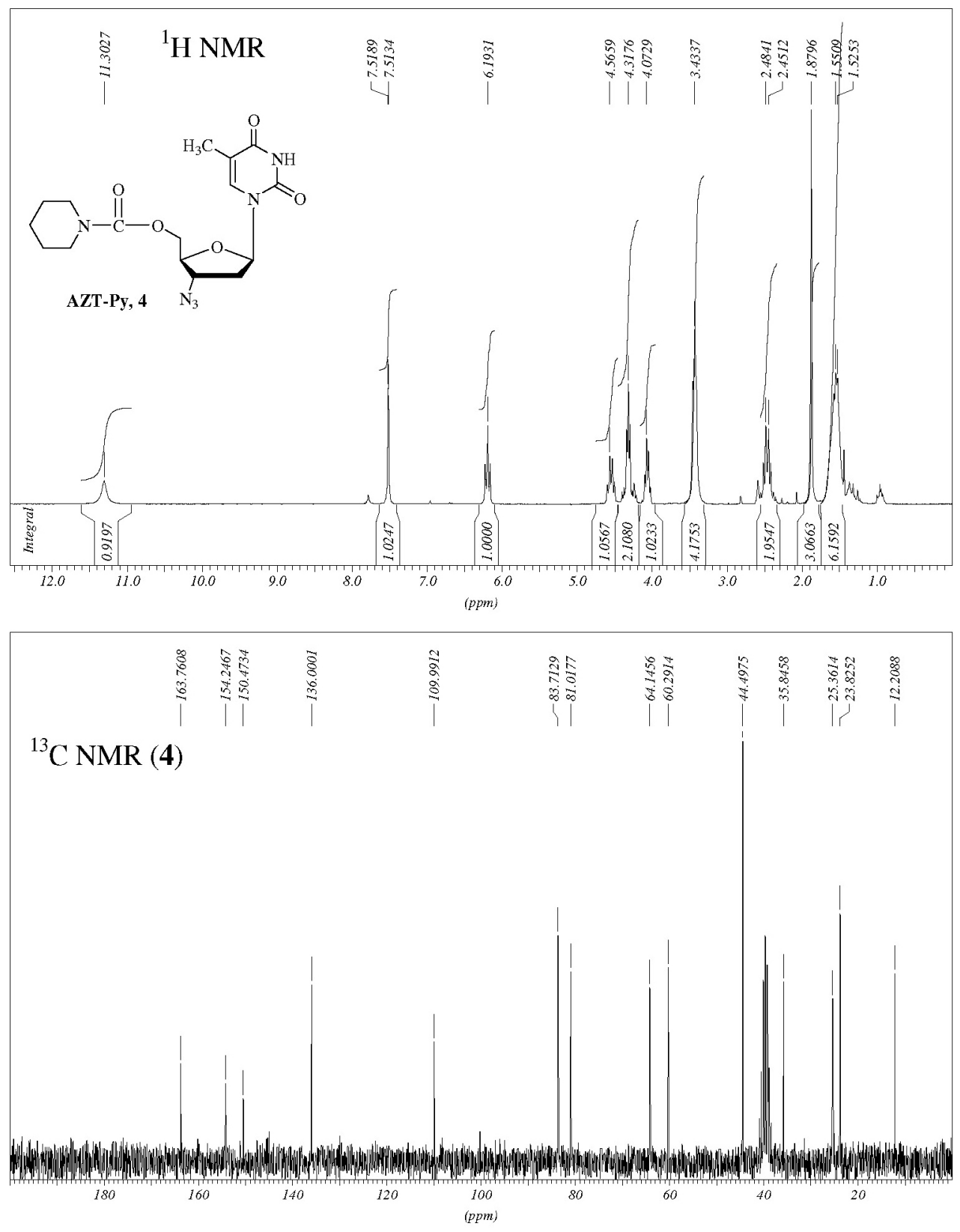

\section{DEPT $135^{\circ}(4)$}

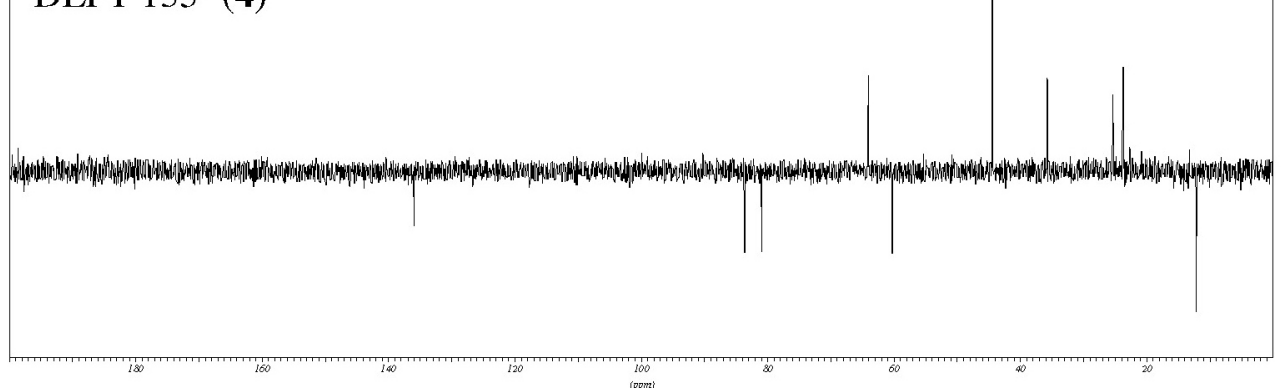

Figure S3a. ${ }^{1} \mathrm{H}$ NMR, ${ }^{13} \mathrm{C}$ NMR, DEPT $135^{\circ}$ of 4 (200 MHz, DMSO-d $)$. 

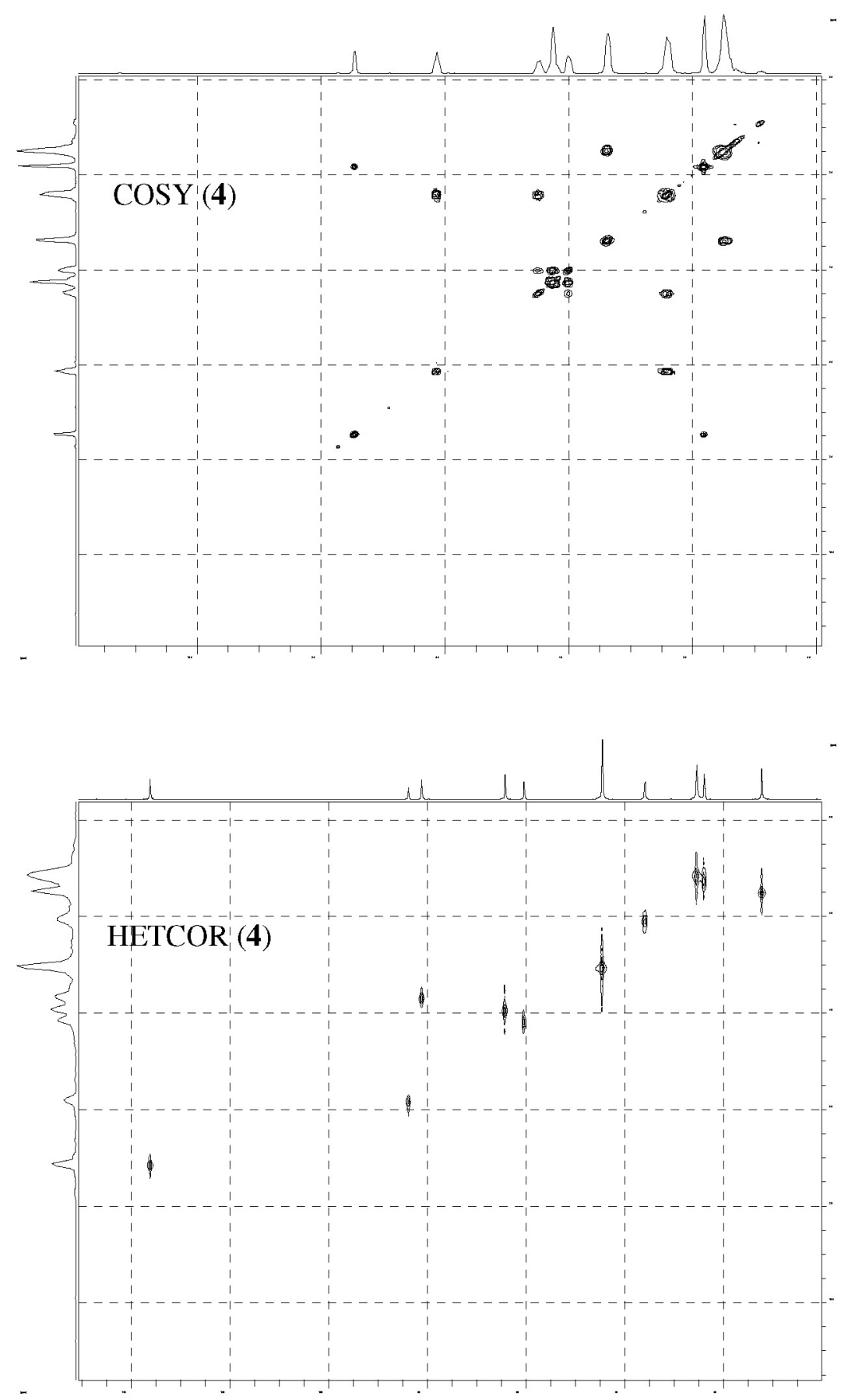

Figure S3b. COSY and HETCOR of 4 (200 MHz, DMSO-d $\left.{ }_{6}\right)$. 

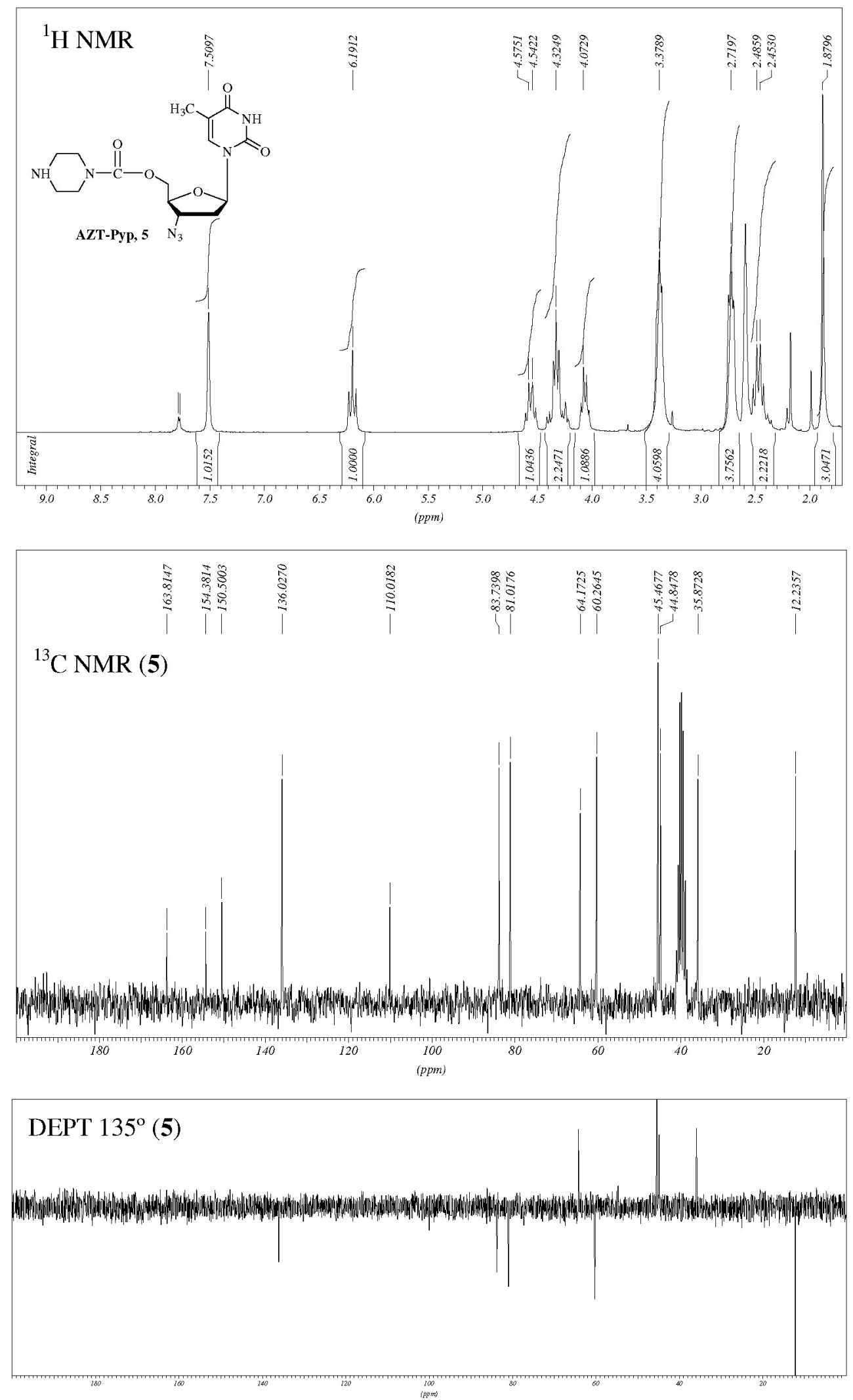

Figure S4a. ${ }^{1} \mathrm{H}$ NMR, ${ }^{13} \mathrm{C}$ NMR, DEPT $135^{\circ}$ of 5 (200 MHz, DMSO-d $)$. 

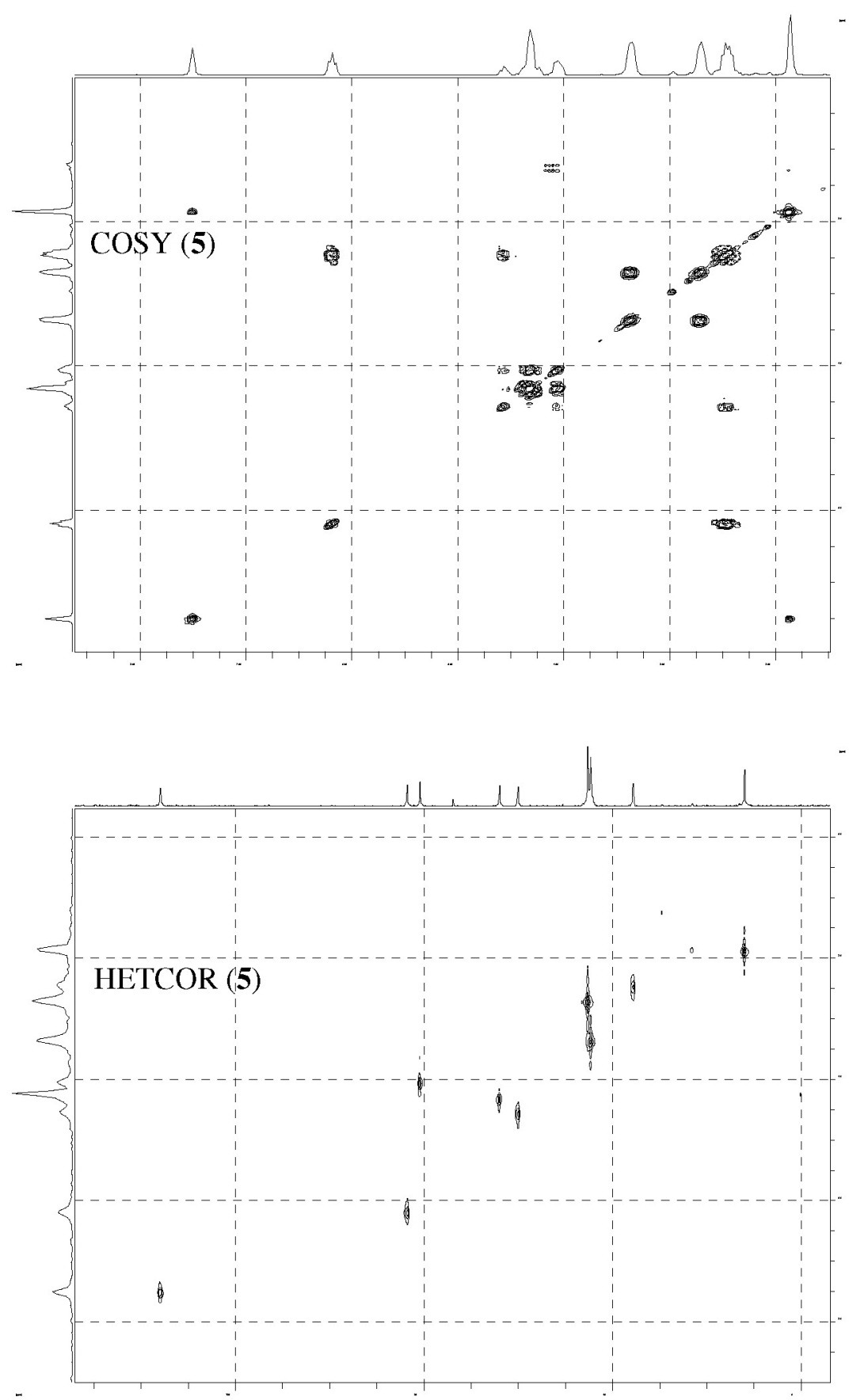

Figure S4b. COSY and HETCOR of 5 (200 MHz, DMSO-d $\left.{ }_{6}\right)$. 

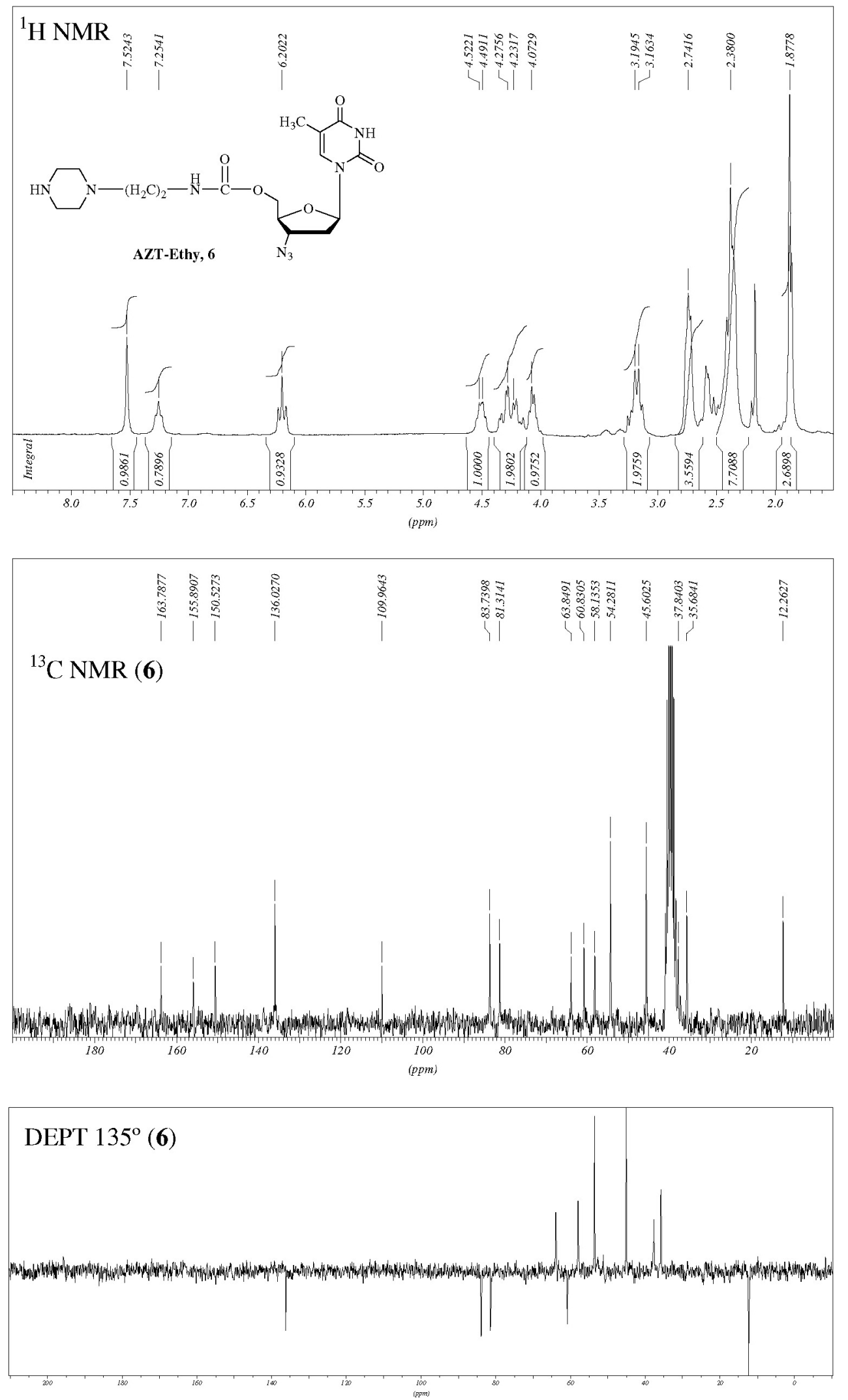

Figure S5a. ${ }^{1} \mathrm{H}$ NMR, ${ }^{13} \mathrm{C}$ NMR, DEPT $135^{\circ}$ of 6 (200 MHz, DMSO-d $)$. 

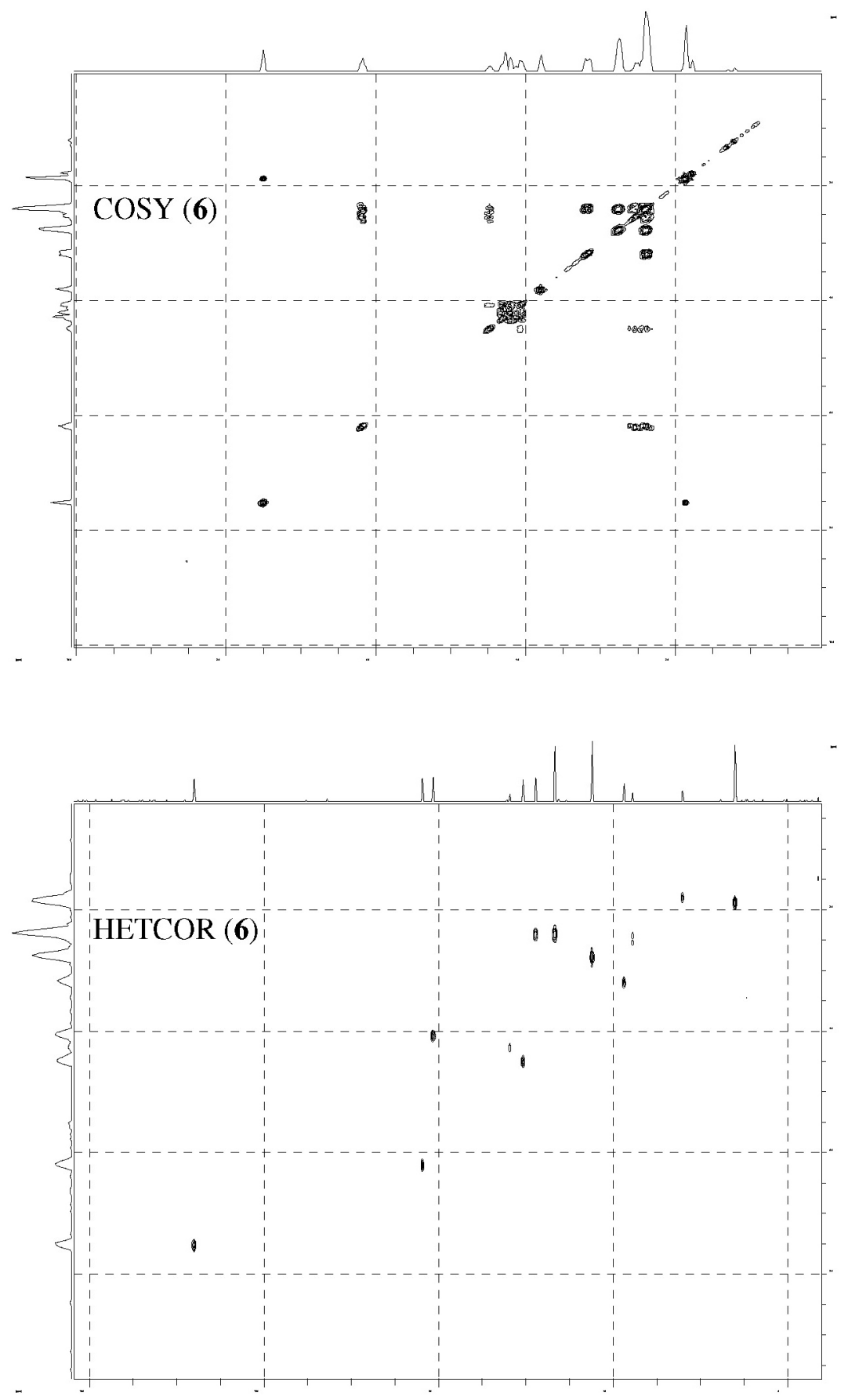

Figure S5b. COSY and HETCOR of 6 (200 MHz, DMSO-d $\mathrm{d}_{6}$. 

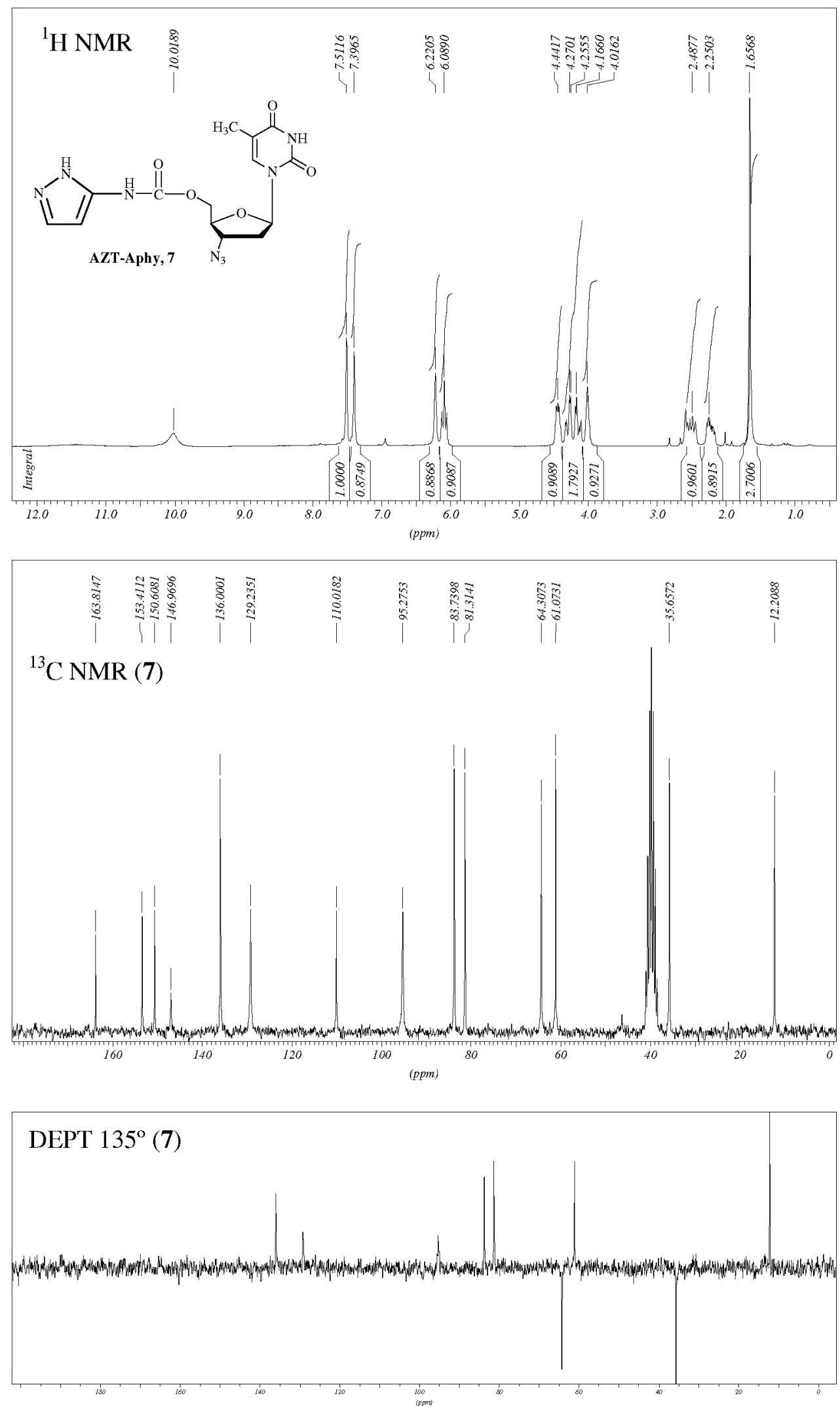

Figure S6a. ${ }^{1} \mathrm{H}$ NMR, ${ }^{13} \mathrm{C}$ NMR, DEPT $135^{\circ}$ of 7 (200 MHz, DMSO-d $)$. 

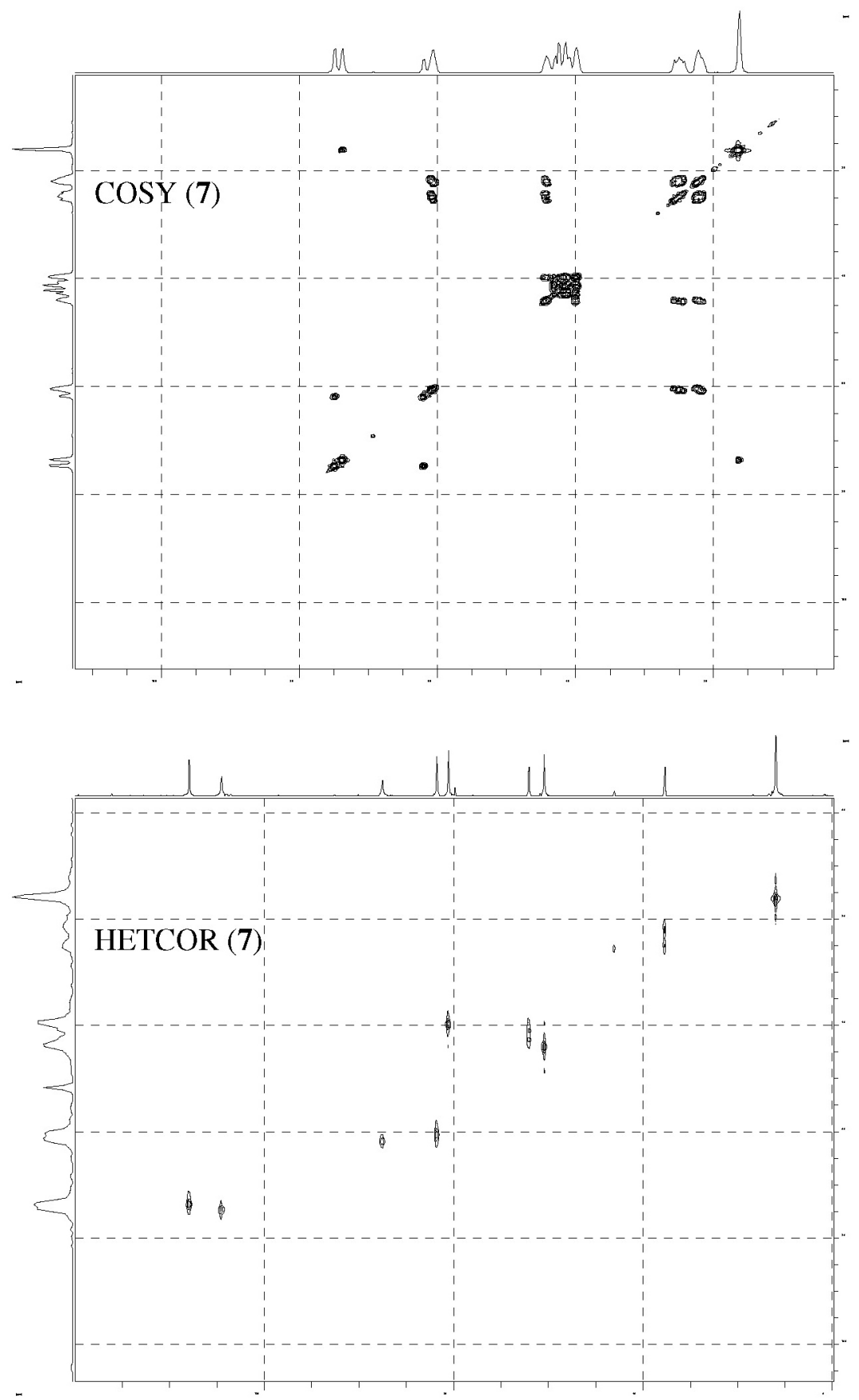

Figure S6b. COSY and HETCOR of 7 (200 MHz, DMSO-d ${ }_{6}$ ). 